\title{
WestVirginiaUniversity
}

THE RESEARCH REPOSITORY @ WVU

Graduate Theses, Dissertations, and Problem Reports

2014

\section{Taxonomy of the Allium cernuum complex in Appalachia}

Rodney David Dever

Follow this and additional works at: https://researchrepository.wvu.edu/etd

\section{Recommended Citation}

Dever, Rodney David, "Taxonomy of the Allium cernuum complex in Appalachia" (2014). Graduate Theses, Dissertations, and Problem Reports. 5484.

https://researchrepository.wvu.edu/etd/5484

This Thesis is protected by copyright and/or related rights. It has been brought to you by the The Research Repository @ WVU with permission from the rights-holder(s). You are free to use this Thesis in any way that is permitted by the copyright and related rights legislation that applies to your use. For other uses you must obtain permission from the rights-holder(s) directly, unless additional rights are indicated by a Creative Commons license in the record and/ or on the work itself. This Thesis has been accepted for inclusion in WVU Graduate Theses, Dissertations, and Problem Reports collection by an authorized administrator of The Research Repository @ WVU. For more information, please contact researchrepository@mail.wvu.edu. 


\title{
Taxonomy of the Allium cernuum complex in Appalachia
}

\author{
Rodney David Dever \\ Thesis submitted to the Eberly College of Arts and Sciences \\ at West Virginia University \\ in partial fulfillment of the requirements of the degree of \\ Master of Science \\ in \\ Biology \\ Donna Ford-Werntz, Ph.D., Chair \\ James McGraw, Ph.D. \\ Jennifer Hawkins, Ph.D. \\ Department of Biology \\ Morgantown, WV \\ 2014
}

Keywords: taxonomy, Allium cernuum, Allium allegheniense, Allium oxyphilum, nodding onion, morphological analysis, Classification And Regression Tree (CART), principal component analysis, cluster analysis, vascular bundle anatomy, breeding systems, shale barren, endemic 


\title{
ABSTRACT \\ Taxonomy of the Allium cernuum complex in Appalachia
}

\author{
Rodney David Dever
}

This study incorporates morphological, anatomical, common garden and breeding system research to investigate whether Allium allegheniense and $A$. oxyphilum merit species status distinct from $A$. cernuum. Herbarium label information was recorded for 1,065 specimens and twelve quantitative and qualitative morphological traits were analyzed using univariate and multivariate techniques. The number and arrangement of scape vascular bundles was observed from nine populations (three from each species). Scapes were sectioned freehand, stained, and examined via light microscopy.

Forty-five plants of the Allium cernuum complex were collected in West Virginia and North Carolina for a common garden study to observe trait variation and phenology. To investigate the breeding system of the $A$. cernuum complex, a crossing experiment was performed in an insect excluded setting. Six representatives of each of the three putative taxa were arranged into two sets of nine (pollen donors and pollen recipients). Plants were also tested for apomixis and autogamy.

Allium allegheniense and $A$. oxyphilum were found to have discrete morphological features (primarily qualitative) that separate them from $A$. cernuum such that they can be recognized as the species proposed by Small (1899) and Wherry (1925). The number of scape vascular bundles ranged between 11 and 27, and the mean was higher than expected. Analysis of variance showed that vascular bundle counts alone do not distinguish the three species.

Morphological differences between the species were maintained in cultivation, although flowering periods overlapped. The flowers appeared to be outcrossing, as the open-pollinated common garden produced more seed set than the insect excluded experiment. Apomixis was not demonstrated, and a low level of self-compatibility was observed. A single putative allogamous cross was successful between $A$. cernuum and $A$. oxyphilum.

In conclusion, flower color, perianth shape and tepal apex were found to be stable in a uniform habitat such that each of the three species can be distinguished. Allium allegheniense consistently had an urceolate perianth and was purple in hue. In $A$. oxyphilum pedicel length was the longest and the obtuse tepals were white with a greenish midrib and base. Geographical and ecological factors likely also impact the species differentiation. 


\section{Table of Contents}

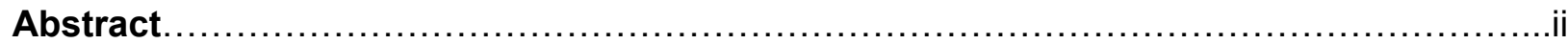

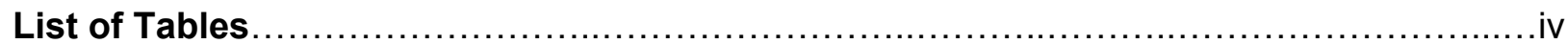

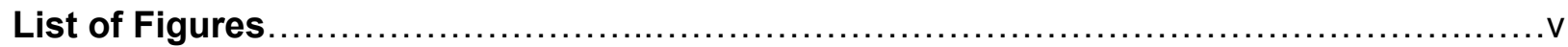

Chapter 1. The Allium cernuum complex in Appalachia: morphology and anatomy

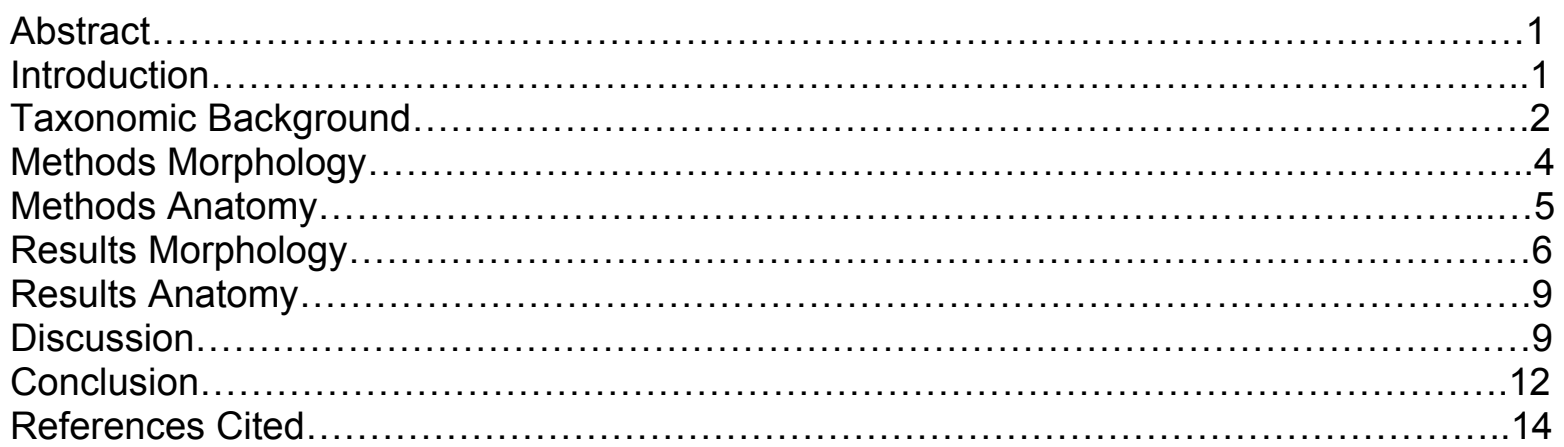

Chapter 2. The Allium cernuum complex in Appalachia: common garden and reproductive biology

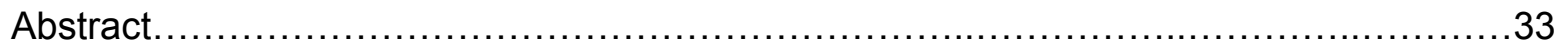

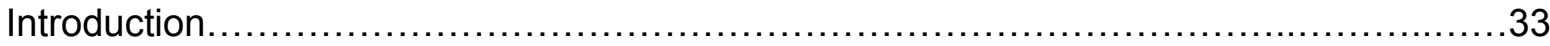

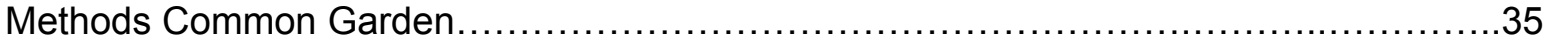

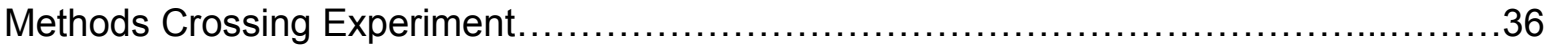

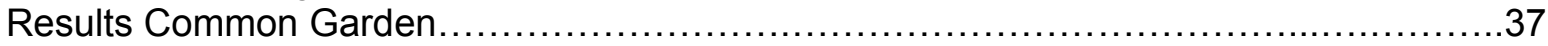

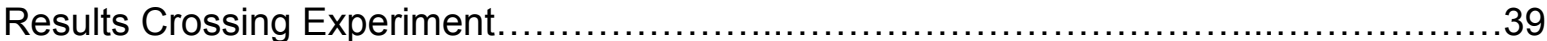

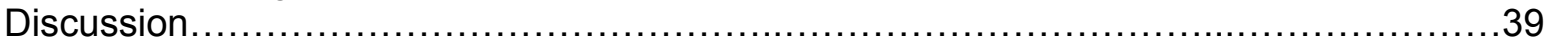

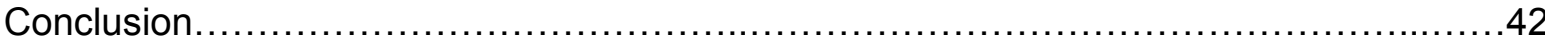

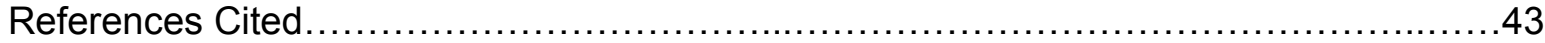

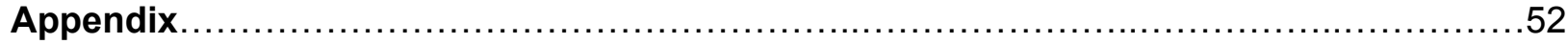

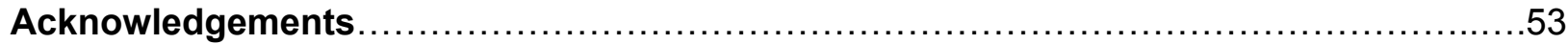




\section{List of Tables}

Table 1-1 The major features of the three putative taxa as indicated by the literature..........17

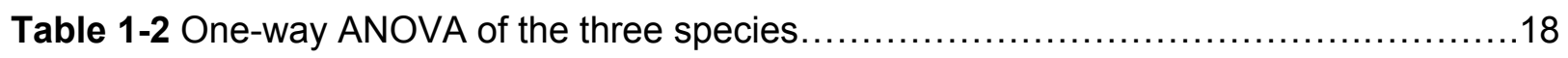

Table 1-3 Principle component analyses of OTUs. Sixty percent of the total variation is explained by the first 3 principal components. The strongest loadings (in bold) match significant univariate statistics. 19

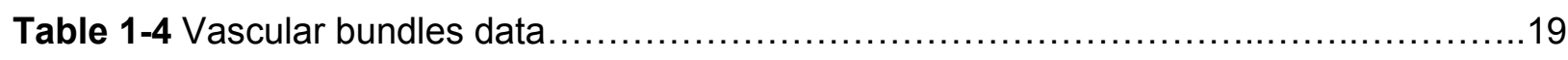

Table 2-1 Collection sites and survival by distance from the common garden. Mortality was greater in plants collected further away from the common garden plot.........................45

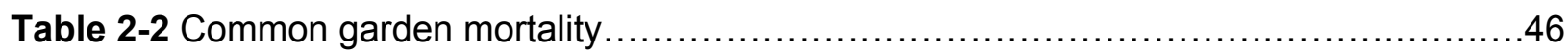

Table 2-3 Qualitative floral morphology in the common garden. Higher Royal Horticultural Color

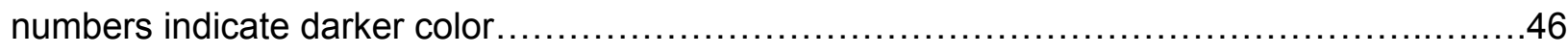

Table 2-4 Qualitative characters in the common garden were stable and differed among species

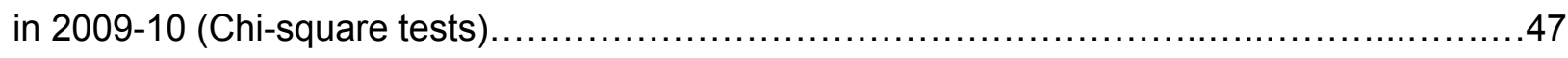

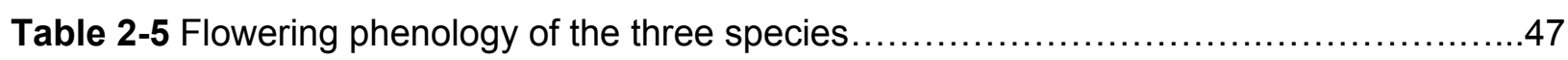

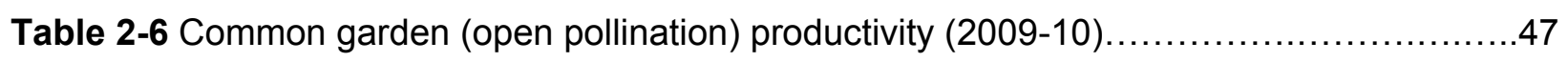

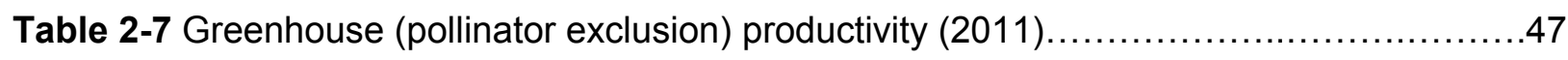

Appendix Vascular bundle counts including field collected and common garden

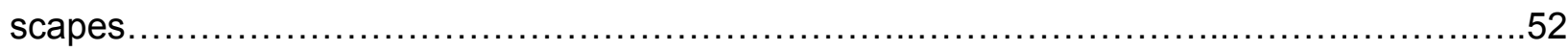




\section{List of Figures}

Figure 1-1 Range of Allium cernuum in North America (McNeal and Jacobsen 2002).........20

Figure 1-2 Map of specimens examined: 1,065 total from 20 herbaria, excluding duplicates and cultivated specimens.

Figure 1-3 State map (NC,VA, WV) showing species by county (Augusta and Bath, Virginia as well as Greenbrier, Mercer and Summers, WV have all three species).

.22

Figure 1-4 (a-g) Seven significant findings in the one-way ANOVA. Levels not indicated by the same letter are significantly different....

..23

Figure 1-5 Cluster analyses of three states (NC, VA and WV). $A=$ Allium allegheniense, $\mathrm{O}=A$. oxyphilum and the colored bars indicate clusters. Unlabeled samples are $A$. cernuum..........24

Figure 1-6 PCA for the entire range east of the Mississippi River. Hulls demarcate the boundaries for the 3 species (represented by the first letter of the specific epithet).... 25

Figure 1-7 PCA for three states (NC, VA and WV). Hulls demarcate the boundaries for the 3 species (represented by the first letter of the specific epithet). 26

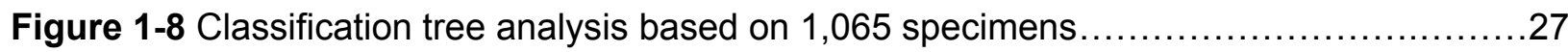

Figure 1-9 Habitat occurance according to herbarium label data. .28

Figure 1-10 The range of $A$. allegheniense in North America is extended to include Georgia, Maryland, and Tennessee. The type locality is in the vicinity of Blowing Rock, NC....

Figure 1-11 Range of $A$. oxyphilum in North America. The type locality is in the vicinity of Lilydale, West Virginia. 30

Figure 1-12 Vascular bundle ranges 31

Figure 1-13 Allium population collection sites: 1) Wildcat Road, 2) Cave Mountain, 3) Smoke Hole, 4) Circleville, 5) Sheets Road, 6) Paddy Mt., 7) Anthony Creek, 8) Kate's Mt., and 9) Lilydale Road.

Figure 2-1 Pink flowers of Allium cernuum with campanulate perianth and acute tepals (common garden plant from 2010, Cave Mt. population, Grant County, WV). 48

Figure 2-2 Urceolate flowers of Allium allegheniense with purple acute tepals (common garden plant from 2010, Circleville population, Pendleton County, WV).

Figure 2-3 Campanulate flower of Allium oxyphilum with white obtuse tepals with green base and midrib (common garden plant from 2010, Anthony Creek population, Greenbrier County, WV).... .50 
Figure 2-4 The outcrossing experiment with 6 representatives of each of the 3 species, divided into 2 treatment groups of 9 pollen donors $(\sigma)$ and pollen recipients $(\boldsymbol{\Phi})$. X = number of crosses

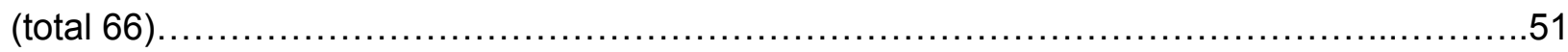

Figure 2-5 Pedicel length in the common garden (2010) was longest in $A$. oxyphilum and $A$. allegheniense. Levels not indicated by the same letter are significantly different................51 


\title{
The Allium cernuum complex in Appalachia: morphology and anatomy
}

\author{
Abstract \\ This study investigates whether Allium allegheniense Small and A. oxyphilum Wherry \\ merit species status as morphologically distinct from $A$. cernuum Roth. Herbarium label \\ information was recorded for 1,065 specimens collected east of the Mississippi River to \\ examine twelve quantitative and qualitative morphological traits and habitat data using \\ univariate and multivariate techniques. $A$. allegheniense and $A$. oxyphilum were found to have \\ discrete features that separate them from $A$. cernuum such that they can be recognized as the \\ species proposed by Small (1899) and Wherry (1925).
}

In Allium cernuum the scape vascular bundle arrangement is not scattered, but develops as a series of concentric rings. This study investigates the number and arrangement of scape vascular bundles of $A$. cernuum, $A$. allegheniense and $A$. oxyphilum. Scapes from nine populations (three from each species) were sectioned freehand, stained, and examined via light microscopy. The number of vascular bundles ranged between 11 and 27 per scape, and the mean was higher than expected. Analysis of variance showed on the basis of vascular bundle counts alone, these putative taxa are not distinguishable.

\section{Introduction}

The Allium cernuum complex in Appalachia consists of three putative species: $A$. cernuum Roth (nodding onion), A. allegheniense Small (Allegheny onion) and A. oxyphilum Wherry (acid-loving onion). Uncertainty as to their taxonomic status is reflected in the literature. At one extreme, the Flora of North America (McNeal and Jacobsen 1997) and Gleason and Cronquist's (1991) Manual of Vascular Plants relegate these taxa to synonymy with A. cernuum. In contrast, The Flora of West Virginia (Strausbaugh and Core 1977), Flora of Virginia (Weakley et al. 2012) and the Plants Database (USDA 2014) all recognize three distinct species. 
However, while Strausbaugh and Core (1977) recognize them as species they still acknowledge that they may all be "forms of the same species." Clearly there is considerable ambiguity.

In most monocotyledons, vascular bundles are typically found throughout the stem and described as "scattered" (Souza 2004). However, in the Allium cernuum complex, vascular bundle arrangement of the scape exhibits two rings. An inner ring, usually of five vascular bundles, encircles the pith while a second ring of cortical bundles flanks the cortex. The arrangement and number of these vascular bundles has been useful diagnostically, to determine species, in the western U.S. A. cernuum alliance (Jacobsen 1978). The typical arrangement of $A$. cernuum is concentric with a mean of 13 vascular bundles per scape (Jacobsen 1978, 1979).

The purpose of this research is to conduct morphological and anatomical analyses to address whether treating the Appalachian Allium cernuum complex as three distinct species is justified. If they differ morphologically or anatomically, then they will meet the criterion for the morphological species concept. Both $A$. oxyphilum and $A$. allegheniense are considered species of conservation concern by NatureServe (2009). The state of West Virginia (WVDNR 2003) and the U.S. Forest Service (USDA 2011) lists A. oxyphilum as a rare and a sensitive species of concern. Determining their taxonomic status will help provide decision makers with information necessary for making appropriate conservation assessments. Rare species, and the ecosystems upon which they depend, may qualify for protection under the 1973 Endangered Species Act.

\section{Taxonomic Background}

In North America north of Mexico, Allium includes 84 species, 81 of which belong to subgenus Amerallium (Wheeler 2013). The A. cernuum complex shares a suite of distinctive features common to the subgenus Amerallium. Namely, they are rhizomatous and have two 
ovarian crests consisting of six flattened processes, two per ovary lobe. Also they all share a chromosome count of $\mathrm{N}=14$.

The most cosmopolitan species of Allium in North America is A. cernuum Roth (Fig. 1-1). Albrecht Wilhelm Roth described A. cernuum in 1798 (Roemer 1798). It consists of an alliaceous aromatic bulb and narrow leaves typical in subgenus Amerallium. The specific epithet denotes the characteristic nodding scape found in all members of the Allium cernuum complex. Six ovate-oblong pale rose to white tepals with acute apices compose a campanulate (flaring) perianth. The blooming period is July and August (Strausbaugh and Core 1977), followed by obovoid capsules. In A. cernuum the 14 chromosomes are usually accompanied by accessory chromosomes (Grun 1959) (Table 1-1).

Two varieties are recognized west of the Mississippi River. Allium cernuum var. obtusum Cockerell ex J.F. Macbr. is found in the United States (AZ, CO, MT, NM, WA, WY) and in Canada (SK). Allium cernuum var. neomexicanum (Rydb.) J.F. Macbr., the New Mexican nodding onion, occurs in the southwest United States (AZ, NM and TX) (USDA 2014).

The status of Allium cernuum segregates in the eastern United States has been debated since John K. Small designated $A$. allegheniense as a species distinct from $A$. cernuum (Small 1899). The tepals are a deep amethyst purple, and the perianth shape is urceolate. The tepals are reported as apically notched, with the outer shorter than the inner. A habitat difference also distinguishes $A$. allegheniense as it is found in thin mafic soils on rocky outcrops in the Appalachians. The blooming period is July and August (Strausbaugh and Core 1977) (Table 11).

Allium oxyphilum Wherry was described by Edgar T. Wherry (1925). This species is characterized by obtuse white tepals with a greenish base and a campanulate perianth. Flowers bloom from August into September (Strausbaugh and Core 1977), later than either A. cernuum 
or A. allegheniense, with capsules becoming broadly deltoid. Accessory chromosomes typical of A. cernuum are likely absent (Grun 1959). It is endemic to highly acidic soils of shale barrens in West Virginia and Virginia (Table 1-1).

\section{Methods Morphology}

Information was recorded for 1,065 specimens (Fig. 1-2) collected east of the Mississippi River from 20 herbaria (BALT, CM, EKY, F, GA, GH, KY, MO, MU, MUHW, NCSC, NCU, NY, OS, PH, TENN, US, VPI, WVA, and WVW). Duplicate and cultivated specimens were excluded.

Label data, recorded for each specimen, included species identification, state and county of collection, site location details (coordinates when available), elevation, habitat, flower color, date of collection, collector name, collector's number, herbarium source, and accession number. Five categories were scored for habitat data: (1) Shale substrate; (2) Forest (includes scrub and edge of woods); (3) Clearing (open spaces including meadow, prairie, field, glade, road, road-cut and railroad); (4) Adjacent to water (wetland, riparian zone, stream, lake, bog, swamp and marsh); (5) Ridge (encompasses slope, ledge, cliff, hillside and summit with no mention of trees). Generally there was little overlap, but when two or more categories were indicated, the order was ranked 1-5. Shale substrate was first in precedence because it is associated Allium oxyphilum, according to the literature (Wherry 1925). The rest are listed in order of frequency referenced on the labels.

Twelve characters ( 4 vegetative and 8 reproductive) were examined for each specimen: (1) stem length (bulb base to umbel), (2) number of leaves (3) leaf length (longest on the herbarium sheet, from base to apex), (4) leaf width (widest part of the widest leaf), (5) number of scapes, (6) number of flowers (largest umbel), (7) pedicel length (longest on specimen), (8) tepal length (base to apex), (9) tepal apex shape (acute or obtuse), (10) tepal color (when discernable or indicated on the label), (11) number of capsules (most robust umbel), and (12) 
capsule process height (crest base to apex). Fruit bearing pedicels are generally thickened so it is evident which bore capsules, even if detached. Measurements were obtained by counting or with a flexible tape measure.

Tepal color descriptions on the labels varied but were scored as four designations: purple, pink, white, or white with green midribs. If the color indicated on the herbarium label is "white" it is considered to be unpigmented unless there is evidence of a colored (green) midrib.

Statistical data analysis and hierarchical clustering were done in SAS-JMP (2007). A one-way analysis of variance was calculated for each of 10 quantitative characters. Transformations were made to maximize normality. Principal component analysis (PCA) and a classification and regression tree (CART) were both performed with the statistical package $\mathrm{R}$ (2012). In addition to analyzing data from the total sample, the region of sympatry (NC, VA and WV) was evaluated as a separate subset and mapped independently. Maps were prepared with ArcGIS 10.1 (ESRI 2012).

\section{Methods Anatomy}

In July 2009, scape sections were field collected from 19 individuals from eight populations in West Virginia. In October 2010, scapes in the common garden (WVU, Life Science Building) were collected from 14 plants. In total they represent 33 individuals, from 9 populations ( 3 from each species as typified by flower color): Allium cernuum tepals being pink, A. allegheniense tepals deep purple and $A$. oxyphilum tepals white with greenish mid-ribs (Fig.1-13).

Scapes were cut into $\sim 5 \mathrm{~mm}$ pieces and immediately fixed with Formalin Acetic Alcohol (FAA), with each scape in a separate glass vial (Johansen 1940). For examination, tissue was 
sectioned freehand and stained with toluidine blue and phloroglucinol (Sass 1958). Slides were examined via light microscopy and evaluated for bundle number and pattern.

A one-way nested ANOVA on count data was done in which taxon was nested within population using SAS-JMP (2007) software. Vouchers of the populations studied are deposited in the West Virginia University Herbarium.

\section{Results Morphology}

Seven of the ten quantitative characters have significant differences (Table1-2).

1. Allium cernuum is taller $(\bar{X}=47.7 \mathrm{~cm})$ than $A$. oxyphilum $(\bar{X}=40.4 \mathrm{~cm})$ and $A$. allegheniense $(\bar{X}=38.9 \mathrm{~cm}),(F=22.18, P<.0001)$, (Fig. 1-4 a).

2. No differences $(F=1.37, P=0.09)$ were found in number of leaves between taxa.

3. Allium cernuum leaf length $(\bar{X}=277 \mathrm{~mm})$ is significantly different $(F=4.72, P=0.0092)$ from $A$. allegheniense $(\bar{X}=248 \mathrm{~mm})$ but $A$. oxyphilum $(\bar{X}=247 \mathrm{~mm})$ was not distinguished from either taxa (Fig. 1-4 b).

4. Allium cernuum leaves are wider $(\bar{X}=3.7 \mathrm{~mm})$ than $A$. oxyphilum $(\bar{X}=3.2 \mathrm{~mm})$ and $A$. allegheniense $(\bar{X}=2.9 \mathrm{~mm}),(\mathrm{F}=14.72, \mathrm{P}<.0001)$, (Fig. 1-4 c).

5. No differences $(F=0.37, P=0.69)$ were found in the number of scapes produced by individual bulbs between taxa.

6. Pedicel length: Allium oxyphilum was longest $(\bar{X}=33 \mathrm{~mm})$, followed by $A$. allegheniense $(\bar{X}=29 \mathrm{~mm})$ and $A$. cernuum $(\bar{X}=28 \mathrm{~mm}),(\mathrm{F}=56.99, \mathrm{P}<.0001),($ Fig. $1-4 \mathrm{~d})$.

7. Allium cernuum had the longest $(F=19.73, P<0001)$ tepal lengths $(\bar{X}=5.2 \mathrm{~mm})$, followed by $A$. allegheniense $(\bar{X}=4.7 \mathrm{~mm}$ ) and $A$. oxyphilum $(\bar{X}=4.4 \mathrm{~mm})$, (Fig. 1-4 e).

8. The most flowers $(F=31.55, P<.0001)$ were exhibited by Allium cernuum $(\bar{X}=35)$, whereas $A$. oxyphilum and $A$. allegheniense both had a mean of 31 (Fig. 1-4 f). 
9. Capsules: Allium cernuum has the most $(F=7.21, P=0.0008)$ fruit $(\bar{X}=19)$. This was significantly more than $A$. oxyphilum $(\bar{X}=14)$. Allium allegheniense was not distinguished from either taxon $(\bar{X}=16)$, (Fig. 1-4 g).

10. No differences $(F=1.61, P=0.20)$ were observed in height of the crest processes found on the capsules.

Hierarchical Clustering Analysis failed to produce clusters based on ten quantitative characters from 196 specimens (not shown). The three state subset $(\mathrm{N}=66)$ also did not cluster specimens by species (Fig. 1-5).

The same ten traits were examined for Principal Components Analysis (PCA) of the 196 specimens (173 Allium cernuum, 16 A. allegheniense and 7 A. oxyphilum). A quantitative difference among the putative taxa is not evident (Fig. 1-6). Eigenvector coefficients of features demonstrate that sixty percent of the total variation is explained by the first 3 principal components. Note that the traits with the strongest loadings match significant univariate statistics (Table 1-3).

The PCA analysis in the three states of NC, VA and WV (66 specimens) is no different than the range as a whole (Fig. 1-7). Hulls demarcate the boundaries for the 3 putative taxa, but the general overlap does not support a quantitative difference between taxa.

The Classification and Regression Tree (CART) analyzes both quantitative and qualitative data. Two qualitative characters were incorporated (color and tepal shape). Flower color was listed on 411 (39\%) of herbarium specimen labels. Some flowers labeled merely "white" on herbarium sheets from Virginia and West Virginia had a green base and midrib. The green color is useful in distinguishing Allium oxyphilum from other taxa that simply lack pigment. 
Tepal shape differs between taxa $(p<.0001$ chi-square). Tepals were mostly acute in Allium cernuum and $A$. allegheniense, but $A$. oxyphilum generally exhibited obtuse tepals. Notched tepals were not observed in any specimens, rather all specimens were found to have entire margins.

CART represents morphological similarity along a vertical axis "tree" in which like OTU's cluster (Fig. 1-8). The resulting dendrogram indicates that tepal shape is an important variable as it occurs at the first bifurcation. It denotes that Allium oxyphilum is distinguished by obtuse tepals and is found in the states of VA and WV (obtuse tepals also occur in some A. cernuum from PA and TN). Pedicel length greater than or equal to $21.5 \mathrm{~mm}$ mostly separates $\mathrm{A}$. oxyphilum from infrequent obtuse tepaled $A$. cernuum and $A$. allegheniense in VA and WV. Allium cernuum and $A$. allegheniense separate by acute tepals. With rare exception, A. cernuum associates with tepals pink (or white misclassified acute A. oxyphilum). Alternatively A. allegheniense has purple tepals (except for two misclassified A. cernuum).

A low error rate of 0.131 indicates that the dendrogram (Fig. 1-8) is a good predictor of this data, however a cross validation error of 1.42 implies that a rare type III error is possible (the right answer for the wrong question). Variation is explained similarly in both the entire and the three state (NC, VA, WV) dataset (not shown).

Allium allegheniense is recorded from six southern states including: NC, VA and WV as well as GA, MD and TN, which are new records, comprising 54 counties in all (Fig. 1-10). A. oxyphilum is found in seven Virginia counties (Augusta, Bath, Craig, Giles, Highland, Patrick and Roanoke) and four counties in West Virginia (Greenbrier, Mercer, Monroe and Summers) (Fig. 1-11). Shale substrate occurs in these regions. These species co-occur with $A$. cernuum in five counties (Fig. 1-3). 


\section{Results Anatomy}

The vascular bundles form two concentric rings (Fig. 1-12), characteristic of Allium cernuum, with a range of between 11 and 27 vascular bundles per scape (Table 1-4, Appendix). In the field data alone, no variation was found in vascular bundle number between species $(P=$ 0.84). The sample size is too small in the common garden alone to detect any variation, but when combined with the field data a difference between populations emerges $(P=0.0005)$.

The counts from the field and common garden can be merged (Cheng 2002) because the trait appears to be genotypic and not phenotypically plastic. There were no differences $(P=$ .86) in vascular bundle number among the species with counts combined. On the basis of vascular bundle counts, the species were found to be indistinguishable.

Differences were observed in elevation $(P<0.002)$ between populations, with more bundles at higher altitudes. However the number of vascular bundles did not appear to show a relationship ( $P=0.79)$ with precipitation (NOAA 2012), nor does there seem to be a link between the number of vascular bundles and the scape length $(P=0.14)$.

\section{Discussion}

The quantitative multivariate analyses do not include qualitative characters such as habitat, color, and shape. Although no significant differences were found with either the PCA or the cluster analysis, other results in this study suggest that Allium allegheniense and $A$. oxyphilum have morphological and ecological features that separate them from $A$. cernuum. They can reasonably be referred to as the species accepted by Small (1899) and Wherry (1925) and best identified following keys in the Flora of West Virginia (Strausbaugh and Core 1977).

Tepal apex shape effectively partitions Allium oxyphilum (obtuse) from the other two species (acute) (Fig. 1-8). Allium allegheniense tepals appear acute, rather than obtuse as 
originally reported. Tepal size was relatively uniform in a given flower, such that the outer tepals are not "manifestly shorter than the inner" (Small 1899).

Tepal color is one of the distinguishing features most mentioned in the literature.

Anthocyanin is the pigment responsible for the colors red, purple and blue in plants. Colors vary subtly within populations, and from one flower to the next. Even a single tepal has a range of color varying from the base (darkest area) to the apex (lightest area). Despite these variations, in the field general color can readily be distinguished and matched with its species (Table 2-3).

Allium allegheniense tepals are typically deep purple whereas $A$. cernuum is predominantly identified as "pink" or "white". On four occasions, however, in specimens well out of the A. allegheniense range, the label indicated "purple". There is no mistaking the deep purple tepals of $A$. allegheniense in the field, yet some $A$. cernuum specimens appear pale violet in shade. These four non-Appalachian specimens were misclassified based on color, but correctly labeled $A$. cernuum.

Wherry (1925) describes Allium oxyphilum as being "green at the base of the sepals and otherwise pure white". The green base and mid-vein is useful in distinguishing A. oxyphilum from other white flowers that simply lack pigment. Also never reported, almost white, $A$. allegheniense tepals were observed in the field in an otherwise typically pigmented population in Circleville, West Virginia. These mutants contrast with the population overall, but the midrib and base still exhibit faint purple coloration. White flowers may have pigment in the ultraviolet range, only perceived by organisms that can detect it. Flowers that appear only white to insects are at a disadvantage in contrast with colored ones and are rare in nature (Kevan 1996).

Classification and Regression Tree Analysis (CART) is useful for plant identification purposes, particularly when dealing with closely related taxa with slight morphological differences (Depypere 2009). The dendrogram (Fig. 1-8) separated most Allium oxyphilum 
based on obtuse tepals, whereas $A$. cernuum and $A$. allegheniense tepals are generally acute. Of the three species $A$. oxyphilum tepals had the shortest mean length $(4.4 \mathrm{~mm})$. The short tepal length may relate to its obtuse contour (Fig. 1-4 e). Perianth shape was not practical to measure in pressed herbarium specimens, however in the field and common garden $A$. allegheniense was urceolate (urn-shaped) whereas $A$. cernuum and $A$. oxyphilum were campanulate (bell-shaped) (Table 2-3).

Allium cernuum is the largest of the three species and differs from the other two in seven of ten quantitative characters. Vegetatively, A. cernuum was the tallest, with wider and longer leaves. In floral traits, $A$. cernuum tepals were longest, and most flowers and capsules were produced.

However, despite being generally smaller overall, Allium oxyphilum has the longest pedicels (Fig. 1-4 d). There is some overlap in pedicel length, on a wide scale (eastern U.S.), however the typical profile of the $A$. cernuum umbel comprises a denser cluster of more flowers. In contrast, the umbel of $A$. oxyphilum is more open, with fewer flowers.

Allium allegheniense and $A$. oxyphilum are both more small and slender than $A$. cernuum. This could be a consequence of nutrient limitations in their extreme habitats. However Wherry (1925) observed that when he planted $A$. oxyphilum in soil with a neutral $\mathrm{pH}$, few viable seeds were produced and proliferation was slower than in other species of Allium. This may involve interspecific competition or indicate that $A$. oxyphilum is adapted to acidic soils.

Allium allegheniense occurs in Appalachian areas where mafic and ultramafic substrates are common. High magnesium levels in the soil select against magnesium intolerant plants and result in scrubby stunted vegetation. As a consequence such areas are called "barrens" and host endemic plants and animals uniquely adapted to theses edaphic features (Alexander 2009). 
Allium oxyphilum occurs on another type of "barren", associated with shale (cited in $41 \%$ of the labels) (Fig. 1-9). As with other shale barren endemics, A. oxyphilum seems to be adapted for survival in thin highly acidic soil. This species is only known from Virginia and West Virginia (Fig. 1-10).

Scape vascular bundle count varies more between populations and counties than between putative species. This suggests that location is more important than taxon identity and that an environmental variable, particularly elevation, may play a role. Physical barriers to gene flow, such as mountains, may explain differences among populations as products of random drift or founder effect. The average bundle count had a higher mean than expected, as all but three counts were above the mean of 13 found by Jacobsen (1979). Six vascular bundles were frequently found in the pith, in contrast to the usual five reported by Jacobsen (1979). Scape diameter should be investigated for possible correlations.

Chromosomes counts were not successful, however Jacobsen (1978) has established that in Allium cernuum $\mathrm{N}=14$. Chromosomes have been counted from populations that included A. oxyphilum, and these were shown to have accessory chromosomes (Grun 1959).

\section{Conclusion}

Although individually significant, quantitative characters did not differentiate between taxa in PCA or cluster analyses. In contrast qualitative characters readily split the species. These emerged prominently in the CART analysis (Fig.1-8).

Allium allegheniense has a deep purple flower and urceolate perianth in the field. However, tepals were observed to be acute, rather than obtuse as originally reported by Small. Its habitat, in the Appalachian Mountains, consists of a mafic substrate. These features are sufficient to recognize this species as accepted by Small (1899). 
Allium oxyphilum flowers are white or white with greenish midribs, have obtuse tepals (with rare exception), and the pedicels often are greater than $21 \mathrm{~mm}$ in length. It occurs primarily on shale substrate in Virginia and West Virginia. Based on this suite of characters, $A$. oxyphilum is supported as a species as accepted by Wherry (1925).

The three taxa did not exhibit significant differences in scape vascular bundle count and so provide no evidence to reject synonymy; however differences between populations were significant. Further investigation is warranted to examine potential ecological and/or size factors as variables affecting scape anatomy.

Based on morphology and geography these taxa are probably separately evolving gene pools isolated by ecology. It has not been demonstrated that they intergrade or hybridize (Chapter 2). Such reproductive evidence would further clarify the nature of the variation to establish taxonomic rank (species vs. variety). 


\section{References Cited}

Alexander, E.B. 2009. Serpentine geoecology of the eastern and southeastern margins of North America. Northeastern Naturalist 16(5): 223-252.

Cheng, W.Y. , P.C. Cheng and D.B. Walden. 2002. The number of vascular bundles in 18 different cultivars of inbred, hybrid or commercial sweet corn. Maize Genetics Cooperation Newsletter 76: 24-25.

Depypere, L., P. Chaerle, K.V. Mijnsbrugge and P. Goetghebeur. 2009. Classification trees and plant identification: a case study of European Prunus section Prunus taxa. Belgian Journal of Botany 142(2): 163-176.

ESRI. 2012. ArcGIS Version 10.1. Environmental Systems Research Institute, Inc., Redlands, CA.

Gleason, H. A. and A. Cronquist. 1991. Manual of the vascular plants of northeastern United States and Canada, 2nd edition. New York, NY. New York Botanic Garden.

Grun, P. 1959. Variability of accessory chromosomes in native populations of Allium cernuum. American Journal of Botany 46(3): 218-224.

Jacobsen, T. D. 1978. A comparative study of three alliances of the genus Allium L., Doctoral dissertation, Washington State University.

Jacobsen, T. D. 1979. Numbers and distributions of vascular bundles in scapes of three alliances of the genus Allium L. (Liliaceae). American Journal of Botany 66(8): 991-992.

Johansen, D.A. 1940. Plant Microtechnique. New York, NY. McGraw-Hill Book Co. 
Kevan, P., M. Giurfa and L. Chittka. 1996. Why are there so many and so few white flowers? Trends in Plant Science 1(8): 280-284.

McNeal, D.W. and T.D. Jacobsen. 2002. Allium. Flora of North America 26: 224-252. New York, NY. Oxford University Press.

National Oceanic \& Atmospheric Administration. 2012. NOAA (www.ncdc.noaa.gov). National Environmental Satellite, Data, and Information Service, Asheville, NC.

NatureServe. 2009. NatureServe Explorer (http://www.natureserve.org/explorer/). Home Office: 1101 Wilson Boulevard, 15th Floor, Arlington, VA.

R Core Team (2013). R: A language and environment for statistical computing. R Foundation for Statistical Computing, Vienna, Austria. http://www.R-project.org/.

Roemer, J. J. 1798. Allium cernuum. Archiv fur die Botanik 1(3): 40. Leipzig.

SAS-JMP. SAS Inst., Inc. 2007. Version 7.01. SAS Institute, Cary, NC.

Sass, J. E. 1958. Botanical Microtechnique, Ames, lowa. The lowa State University Press.

Small, J.K. 1899. Undescribed species from the southern United States. Bulletin of the New York Botanic Garden 1: 278-280.

Souza, L. A., I.S. Moscheta and J.H.G. Oliveira. 2004. Comparative morphology and anatomy of the leaf and stem of Peperomia dah/stedtii C. DC., Ottonia Martiana Miq. and Piper diospyrifolium Kunth (Piperaceae). Gayana Botany 61(1): 6-17.

Strausbaugh P.D. and E. L. Core. 1977. Flora of West Virginia, 2nd Edition. Grantsville, WV. Seneca Books Inc. 
USDA, Forest Service. 2011. Sensitive Species Summary (http://www.fs.usda.gov/lnternet/FSE DOCUMENTS/fsm8 035767.pdf).

USDA, NRCS. 2014. The PLANTS Database (http://plants.usda.gov, 12 July 2014). National Plant Data Team, Greensboro, NC.

Weakley, A. S., J.C. Ludwig and J.F. Townsend. 2012. Flora of Virginia. Foundation of the Flora of Virginia Project Inc., Fort Worth, TX. Botanical Research Institute of Texas.

West Virginia Department of Natural Resources. 2003. Rare, threatened and endangered Plants - West Virginia Natural Heritage Program (http://www.wvdnr.gov/Wildlife/PDFFiles/Plantsnew.pdf).

Wheeler, E.J., S. Mashayekhi, D.W. McNeal, J.T. Columbus and J.C. Pires. 2013. Molecular systematics of Allium subgenus Amerallium (Amaryllidaceae) in North America. American Journal of Botany 100(4): 701-11.

Wherry, E.T. 1925. A new acid-soil onion from West Virginia. Journal of the Washington Academy of Sciences 15: 370-371. 


\begin{tabular}{|l|c|c|c|}
\hline \multicolumn{1}{|c|}{ Features } & Allium cernuum & Allium allegheniense & Allium oxyphilum \\
\hline $\begin{array}{l}\text { Perianth } \\
\text { Shape }\end{array}$ & campanulate & urceolate & campanulate \\
\hline Perianth Color & white to pale rose & deep purple & $\begin{array}{c}\text { white with green } \\
\text { base and midrib }\end{array}$ \\
\hline Tepals & acute, apex entire & $\begin{array}{c}\text { outer tepals obtuse, shorter } \\
\text { than inner, apex notched }\end{array}$ & obtuse, apex entire \\
\hline Capsule & obovoid & unknown & broadly deltoid \\
\hline $\begin{array}{l}\text { Blooming } \\
\text { Time }\end{array}$ & July-August & July-August & August-September \\
\hline $\begin{array}{l}\text { Accessory } \\
\text { Chromosomes }\end{array}$ & often present & rocky mafic outcrops & probably absent \\
\hline Habitat & prairies & WV, VA and NC (possibly in \\
TN and GA?) & WV and VA \\
\hline Geography & throughout much of North \\
\end{tabular}

Table 1-1 The major features of the three putative taxa as indicated by the literature. 


\begin{tabular}{|c|c|c|c|c|c|c|c|}
\hline \multirow[b]{2}{*}{ Character } & \multicolumn{2}{|c|}{ Allium cernuum } & \multicolumn{2}{|c|}{$\begin{array}{l}\text { Allium } \\
\text { allegheniense }\end{array}$} & \multicolumn{2}{|c|}{ Allium oxyphilum } & \multirow[b]{2}{*}{ p-value } \\
\hline & Mean & Range & Mean & Range & Mean & Range & \\
\hline $\begin{array}{l}\text { Stem Length } \\
\text { (Bulb + Scape) } \\
\text { cm }\end{array}$ & 47.7 & $\begin{array}{l}20.5- \\
89.5\end{array}$ & 38.9 & $22.6-57.3$ & 40.4 & $\begin{array}{l}21.3- \\
71.3\end{array}$ & $\begin{array}{l}p= \\
0.0001\end{array}$ \\
\hline $\begin{array}{l}\text { Number of } \\
\text { Scapes }\end{array}$ & 1 & $1-3$ & 1 & $1-3$ & 1 & $1-2$ & $p=0.64$ \\
\hline $\begin{array}{l}\text { Number of } \\
\text { Leaves }\end{array}$ & 6 & $1-15$ & 6 & $1-14$ & 6 & $1-17$ & $p=0.09$ \\
\hline $\begin{array}{l}\text { Leaf Width } \\
\text { mm }\end{array}$ & 3.7 & $1-10$ & 3 & $1-7$ & 3 & $1-10$ & $\begin{array}{l}p= \\
0.0001\end{array}$ \\
\hline $\begin{array}{l}\text { Leaf Length } \\
\mathrm{mm}\end{array}$ & 277.4 & $35-547$ & 248 & $58-450$ & 247 & $101-422$ & $\begin{array}{l}p= \\
0.0092\end{array}$ \\
\hline $\begin{array}{l}\text { Number of } \\
\text { Flowers }\end{array}$ & 34 & $7-93$ & 25 & $8-61$ & 25 & $5-57$ & $\begin{array}{l}p= \\
0.0001\end{array}$ \\
\hline $\begin{array}{l}\text { Pedicel } \\
\text { Length } \\
\text { Longest } \mathrm{mm}\end{array}$ & 17 & $3-55$ & 19 & $6-38$ & 28 & $11-47$ & $\begin{array}{l}p= \\
0.0001\end{array}$ \\
\hline $\begin{array}{l}\text { Tepal length } \\
\text { mm }\end{array}$ & 5.2 & $3.5-7.5$ & 5 & $3-7$ & 4 & $3-5.5$ & $\begin{array}{l}p= \\
0.0001\end{array}$ \\
\hline $\begin{array}{l}\text { Number of } \\
\text { Capsules }\end{array}$ & 9 & $1-50$ & 7 & $1-26$ & 5 & $1-18$ & $\begin{array}{l}p= \\
0.0008\end{array}$ \\
\hline $\begin{array}{l}\text { Crest/Process } \\
\text { Height } \mathrm{mm}\end{array}$ & 1.3 & $0.5-2$ & 1 & $1-2$ & 1 & $1-2$ & $p=0.24$ \\
\hline
\end{tabular}

Table 1-2 One-way ANOVA of the three species. 


\begin{tabular}{|l|l|l|l|}
\hline Character & PC 1 Loadings & PC 2 Loadings & PC 3 Loadings \\
\hline Stem Length & -0.7731448 & 0.21314386 & -0.1162426 \\
\hline Scapes Number & -0.3395913 & -0.45385784 & -0.2490657 \\
\hline Leaf Width & -0.7460947 & -0.27538325 & 0.2202997 \\
\hline Leaves Number & -0.3154922 & -0.39973767 & 0.5514296 \\
\hline Leaf Length & $-\mathbf{0 . 6 9 8 3 1 7 3}$ & -0.28695686 & 0.2806157 \\
\hline Pedicels/Flowers Number & $-\mathbf{0 . 7 0 2 1 1 9 2}$ & 0.27219034 & -0.1906232 \\
\hline Pedicel Length & -0.4540019 & -0.30620022 & -0.2633681 \\
\hline Capsules Number & -0.3782167 & 0.07426193 & -0.6680731 \\
\hline Crest Height & -0.3059623 & 0.59368371 & 0.2216139 \\
\hline Tepal Length & -0.3537490 & 0.73349095 & 0.2217353 \\
\hline
\end{tabular}

Table 1-3 Principle component analyses of OTUs. Sixty percent of the total variation is explained by the first 3 principal components. The strongest loadings (in bold) match significant univariate statistics.

\begin{tabular}{|c|c|c|c|c|c|c|}
\hline \multirow[t]{2}{*}{ Species } & \multicolumn{2}{|c|}{ Field Collected } & \multicolumn{2}{|c|}{ Common Garden } & \multirow{2}{*}{$\begin{array}{c}\text { Combined } \\
\text { Mean }\end{array}$} & \multirow[t]{2}{*}{$\mathbf{N}$} \\
\hline & Counts & Mean & Counts & Mean & & \\
\hline cernuum & $15,16,16,16,17,17,19$ & 16.6 & $14,15,17,19,21$ & 17.2 & 16.8 & 12 \\
\hline allegheniense & $14,15,16,18$ & 15.8 & $12,16,17,17,18$ & 16 & 15.9 & 9 \\
\hline oxyphilum & $\begin{array}{c}11,13,17,19,19,24, \\
26,27\end{array}$ & 19.5 & $15,17,19,21$ & 18 & 19 & 12 \\
\hline
\end{tabular}

Table 1-4 Vascular bundles data. 


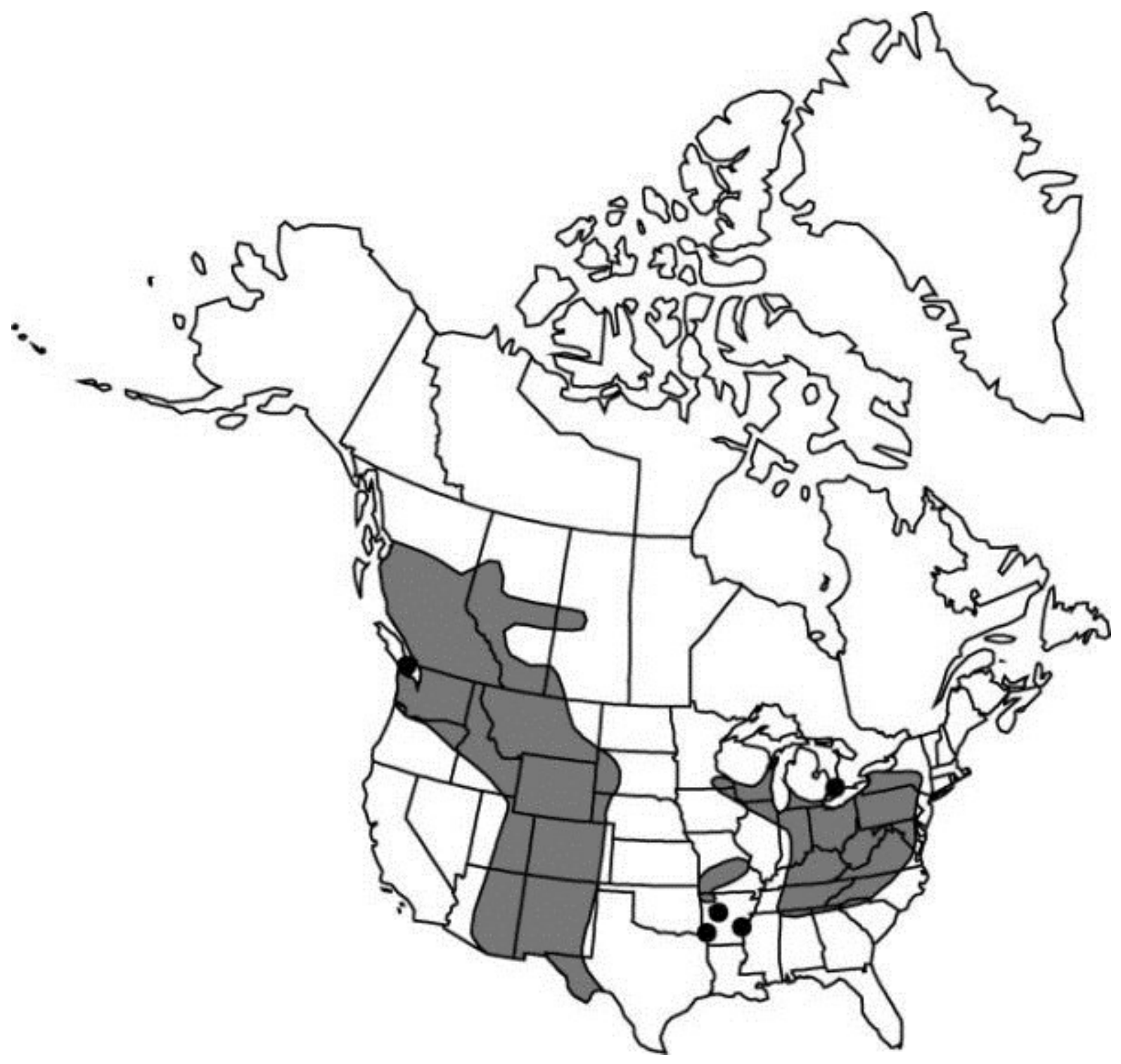

Figure 1-1 Range of Allium cernuum in North America (McNeal and Jacobsen 2002). 


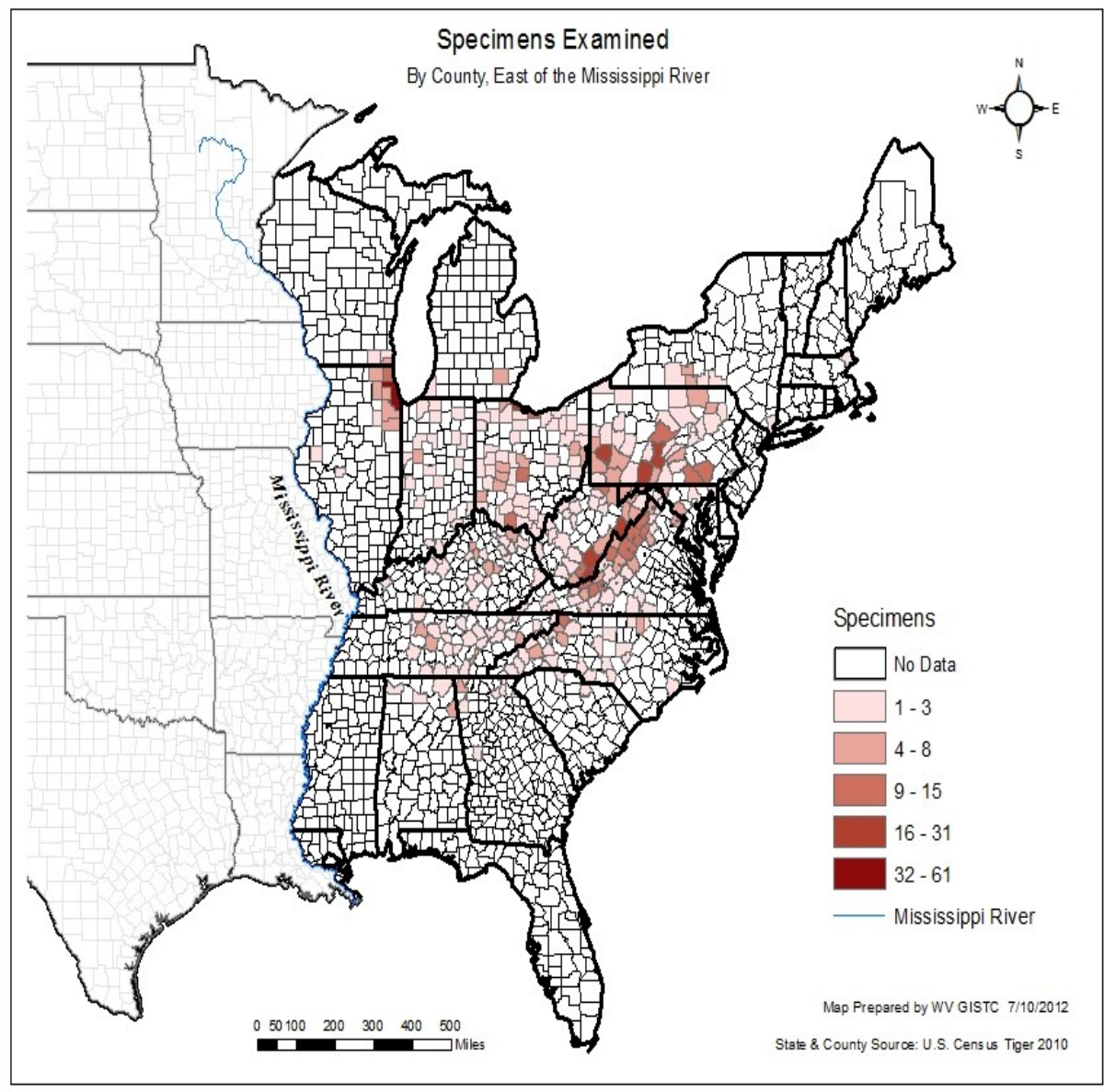

Figure 1-2 Map of specimens examined: 1,065 total from 20 herbaria, excluding duplicates and cultivated specimens. 


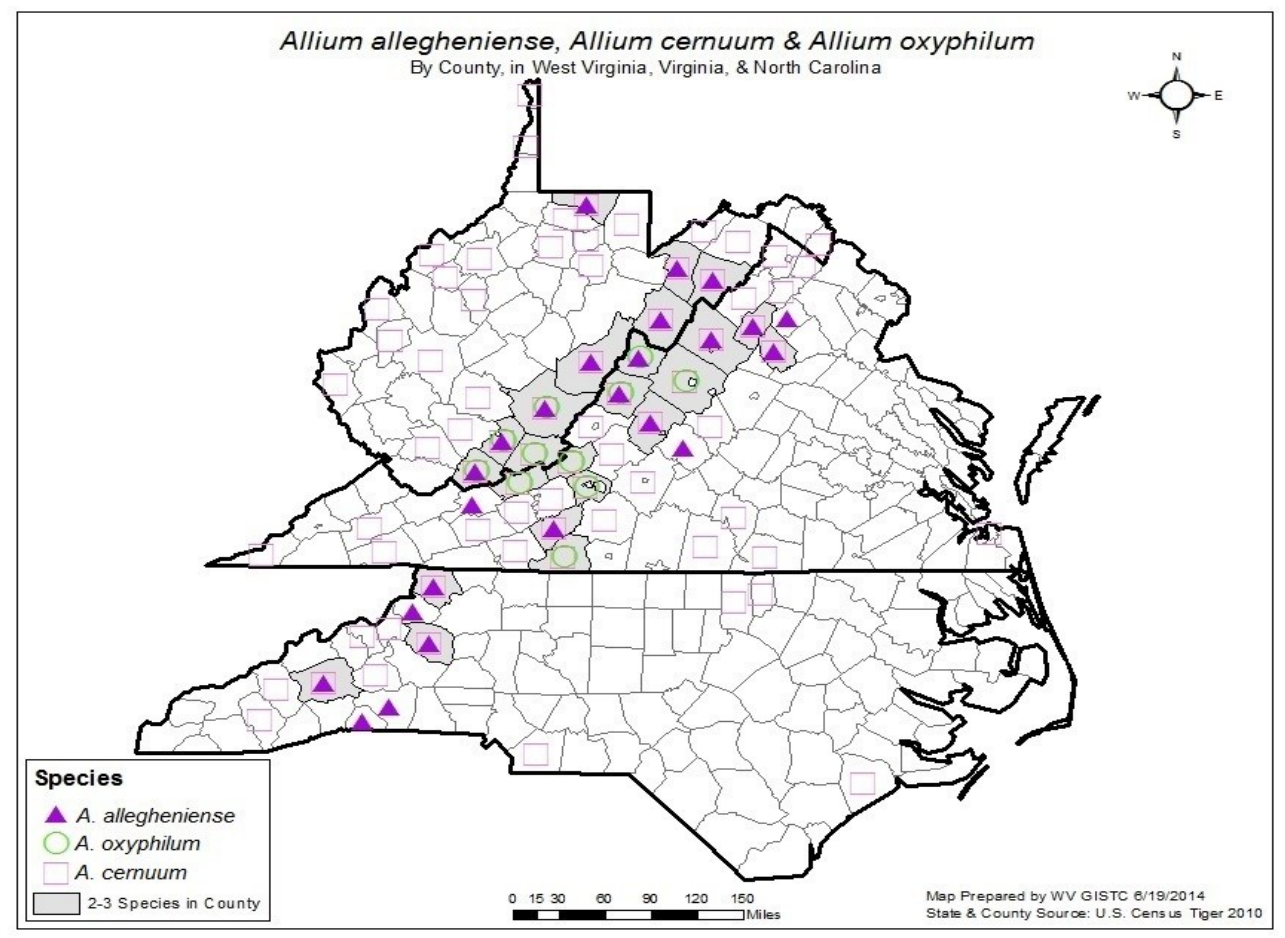

Figure 1-3 State map (NC,VA, WV) showing species by county (Augusta and Bath, Virginia as well as Greenbrier, Mercer and Summers, WV have all three species). 


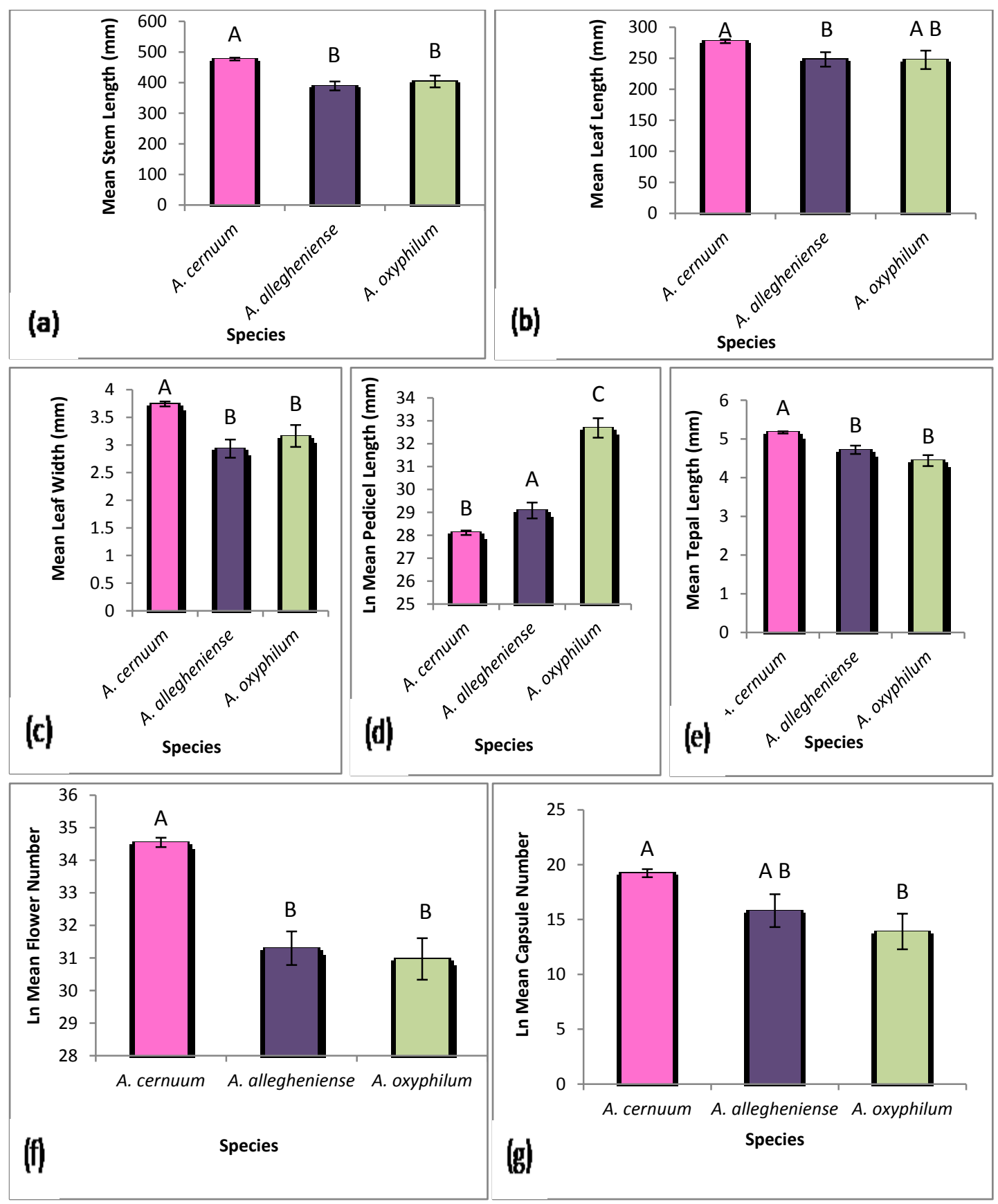

Figure 1-4 (a-g) Seven significant findings in the one-way ANOVA. Levels not indicated by the same letter are significantly different. 


\section{Hierarchical Clustering}

\section{Dendrogram}

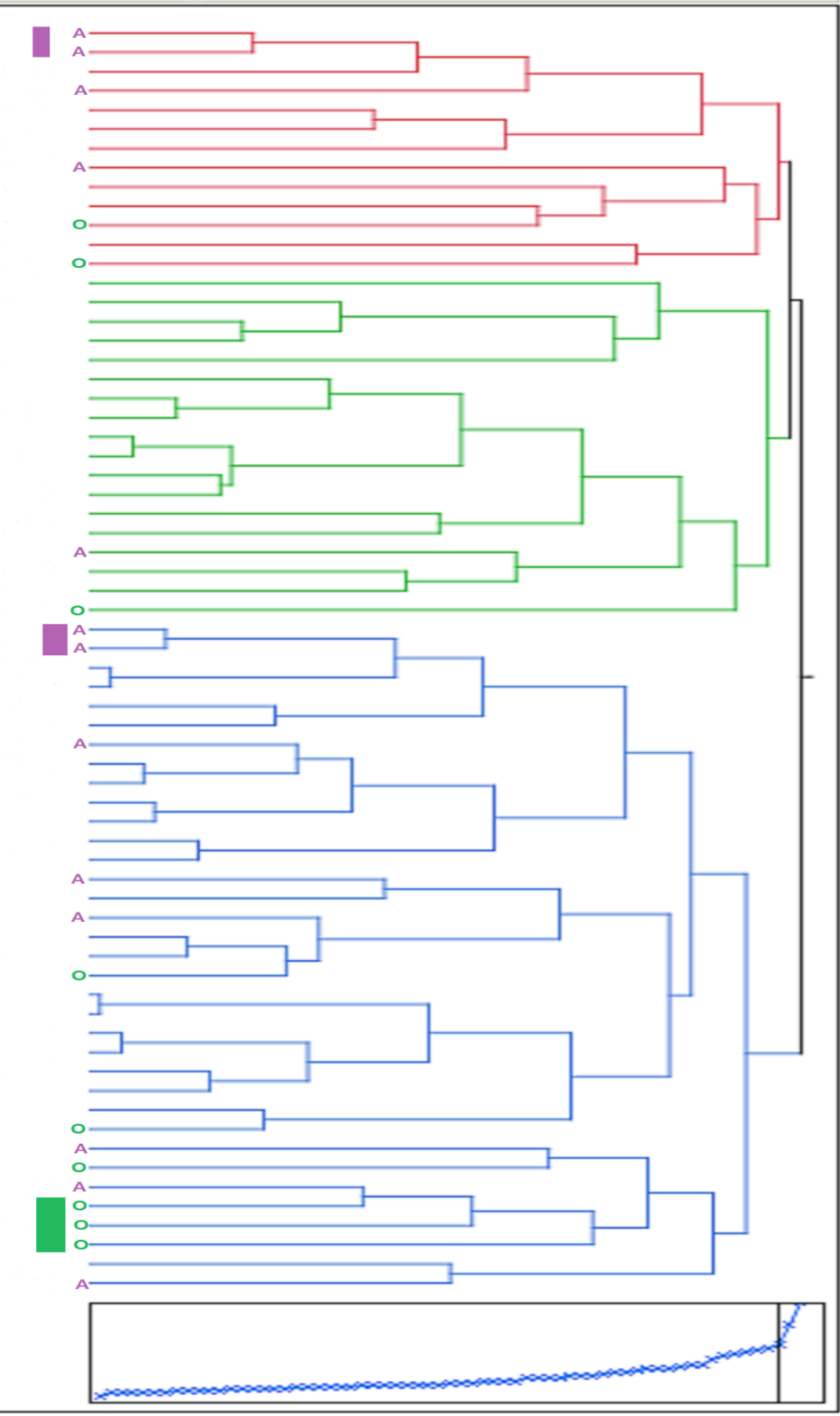

Figure 1-5 Cluster analyses of three states (NC, VA and WV). $A=$ Allium allegheniense, $\mathrm{O}=A$. oxyphilum and the colored bars indicate clusters. Unlabeled samples are A. cernuum. 


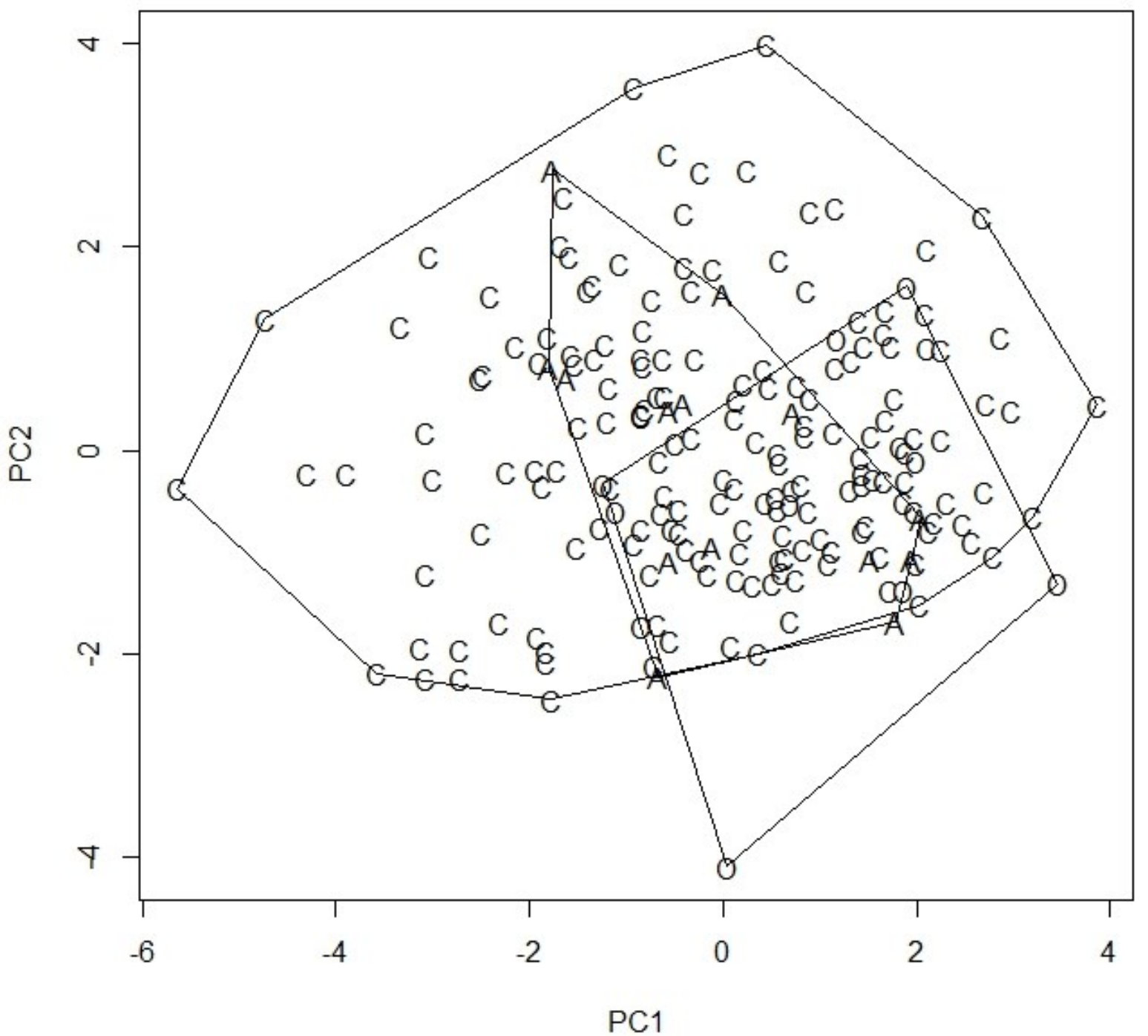

Figure 1-6 PCA for the entire range east of the Mississippi River. Hulls demarcate the boundaries for the 3 species (represented by the first letter of the specific epithet). 


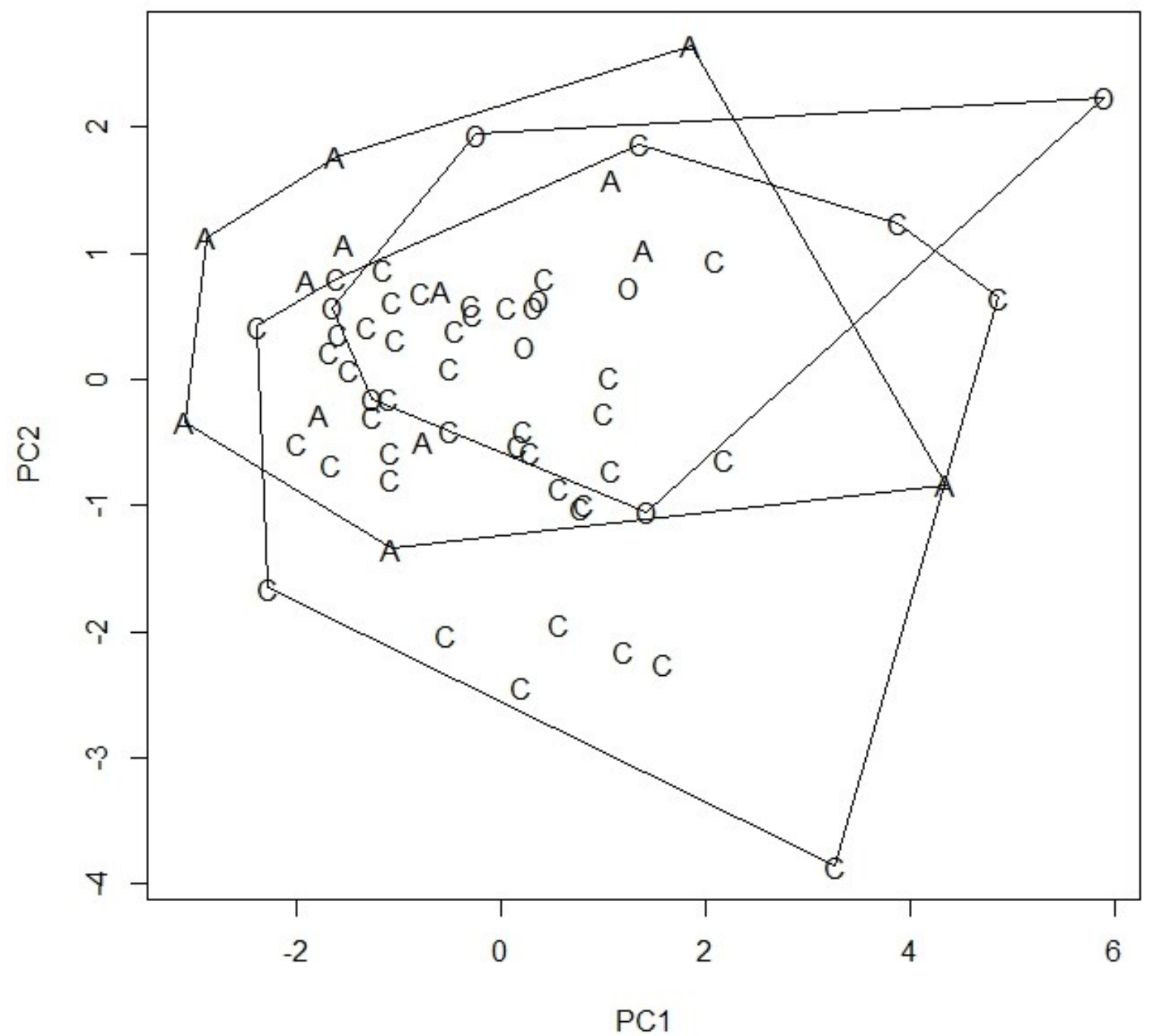

Figure 1-7 PCA for three states (NC, VA and WV). Hulls demarcate the boundaries for the 3 species (represented by the first letter of the specific epithet). 


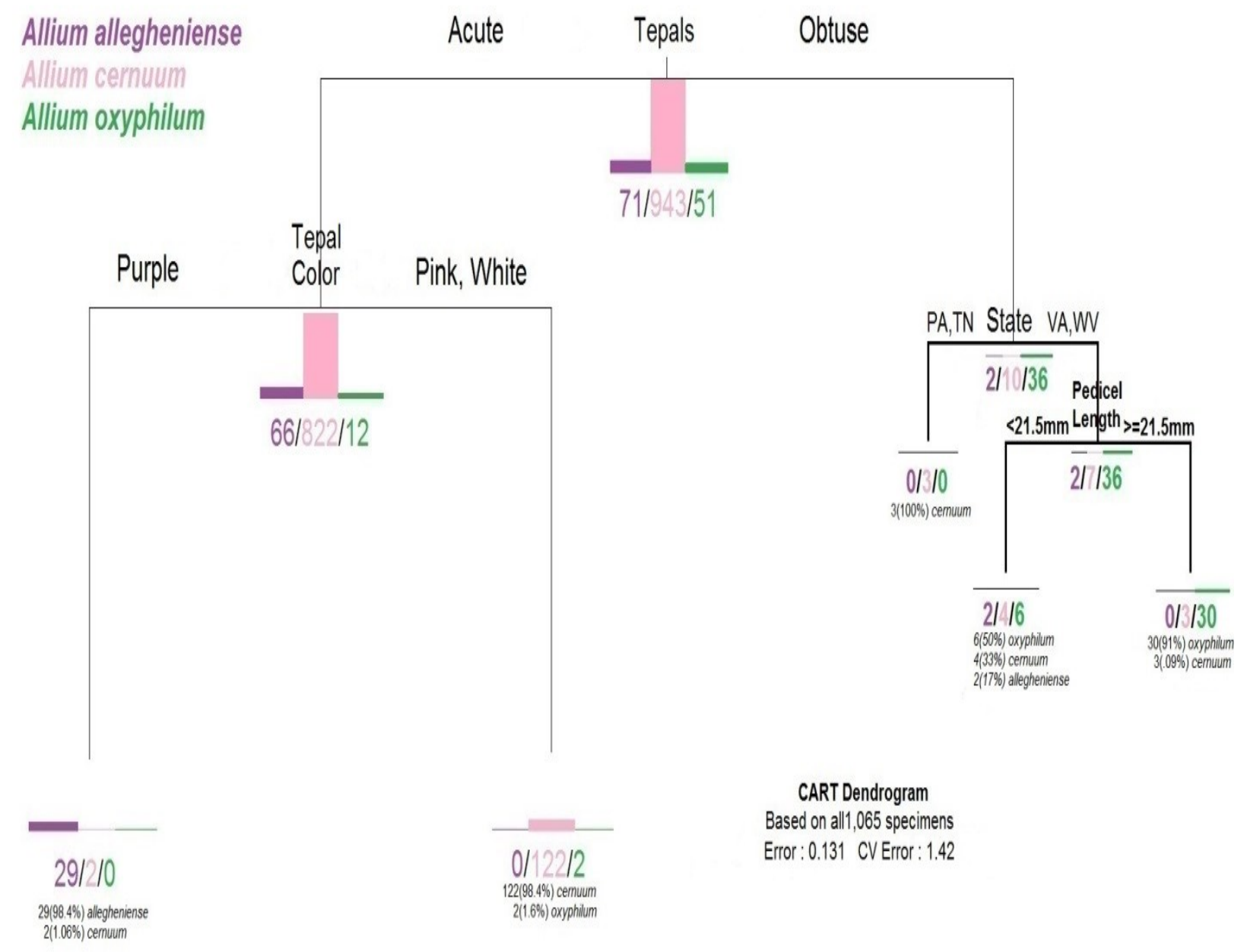

Figure 1-8 Classification tree analysis based on 1,065 specimens. 

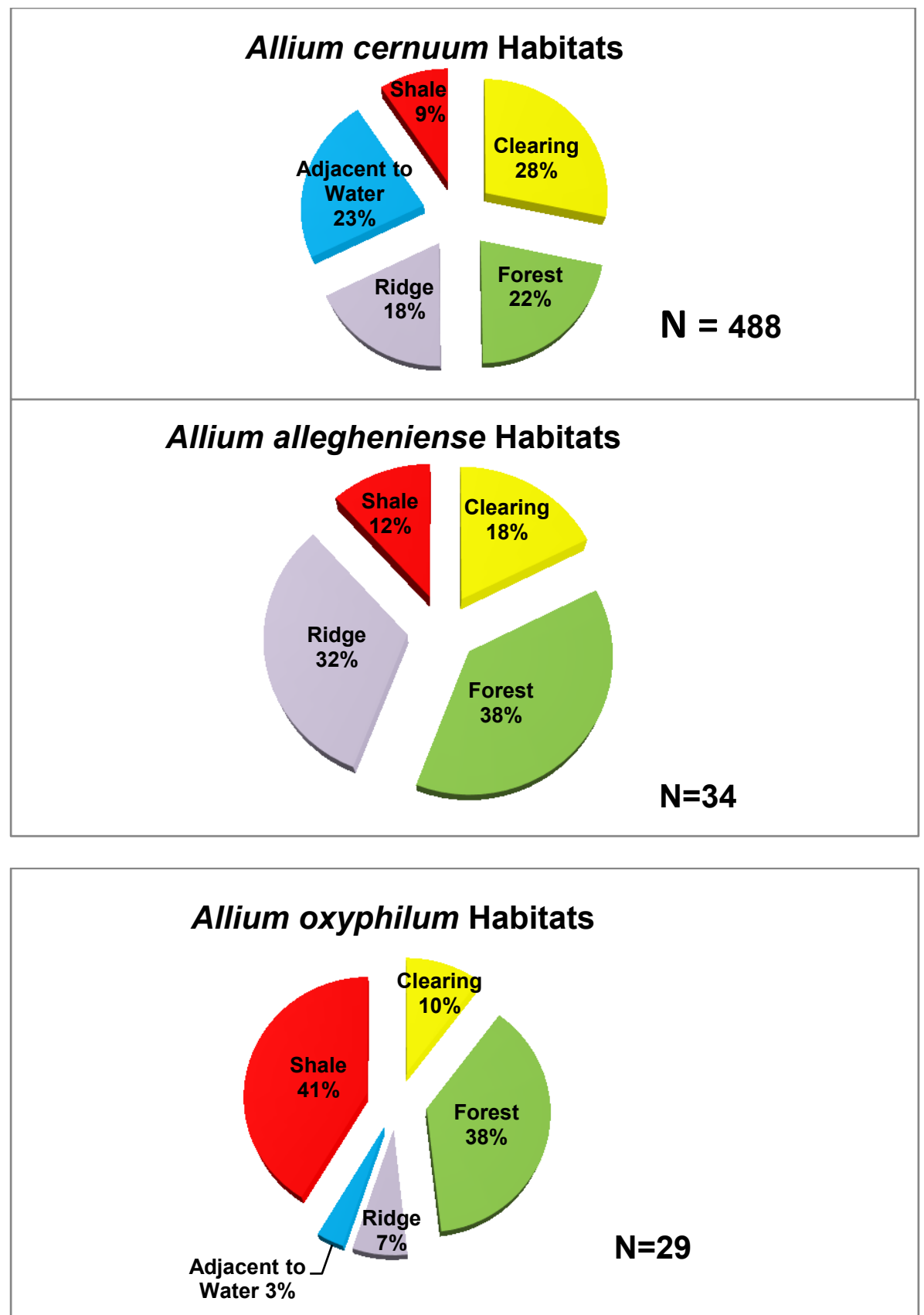

Figure 1-9 Habitat occurance according to herbarium label data. 


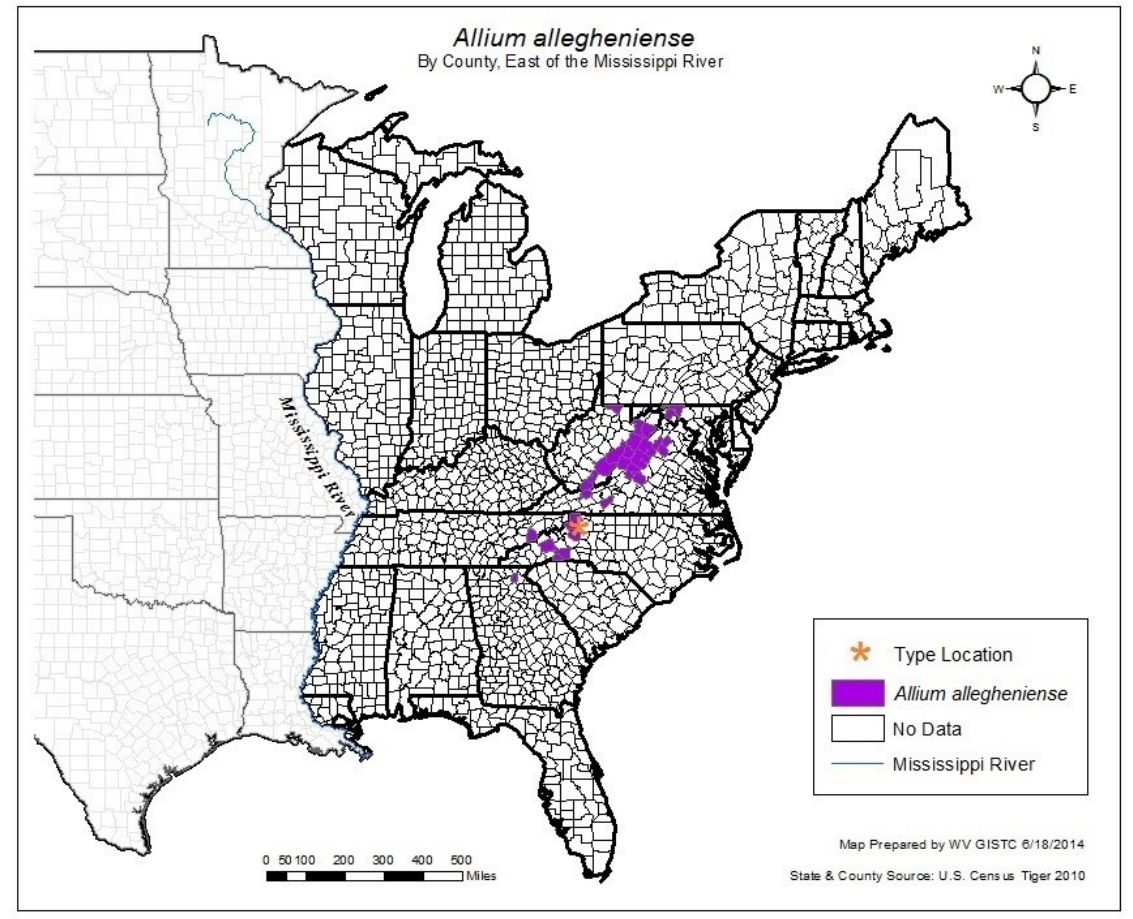

Figure 1-10 The range of $A$. allegheniense in North America is extended to include Georgia, Maryland, and Tennessee. The type locality is in the vicinity of Blowing Rock, North Carolina. 


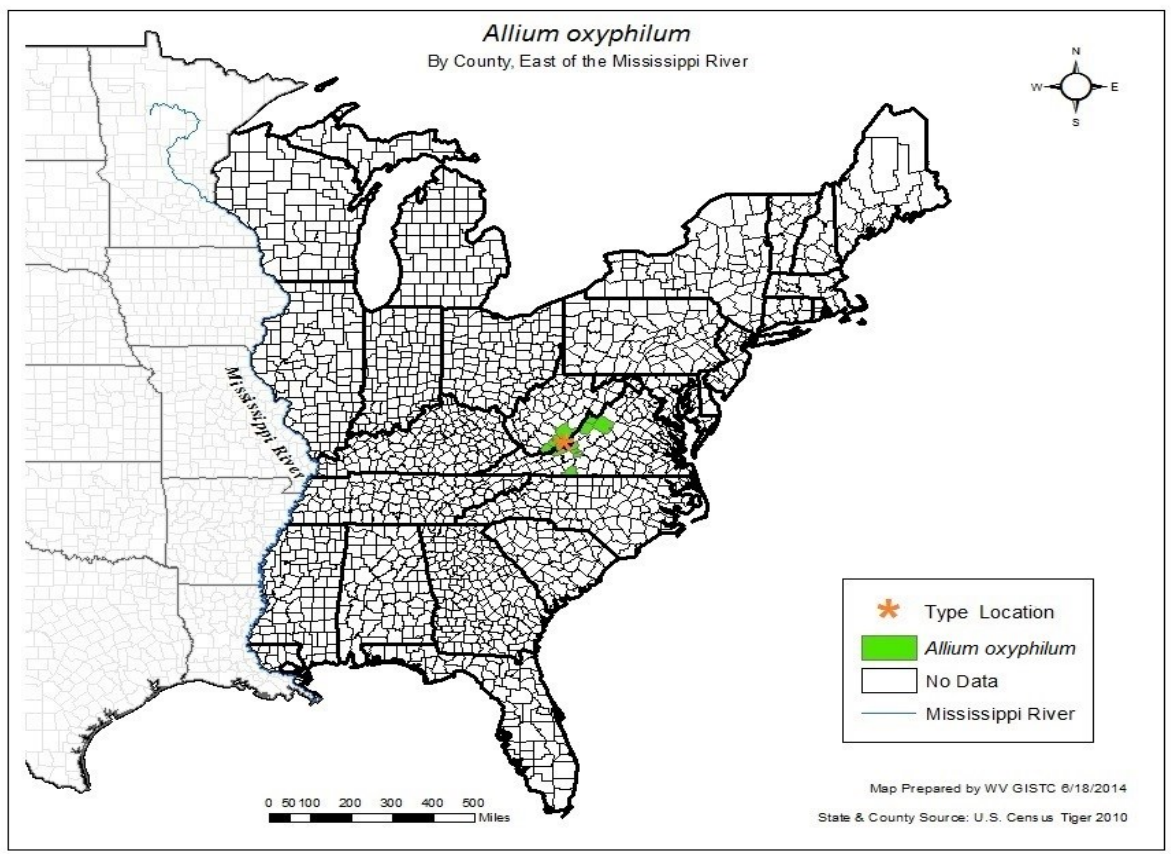

Figure 1-11 Range of $A$. oxyphilum in North America. The type locality is in the vicinity of Lilydale, West Virginia. 


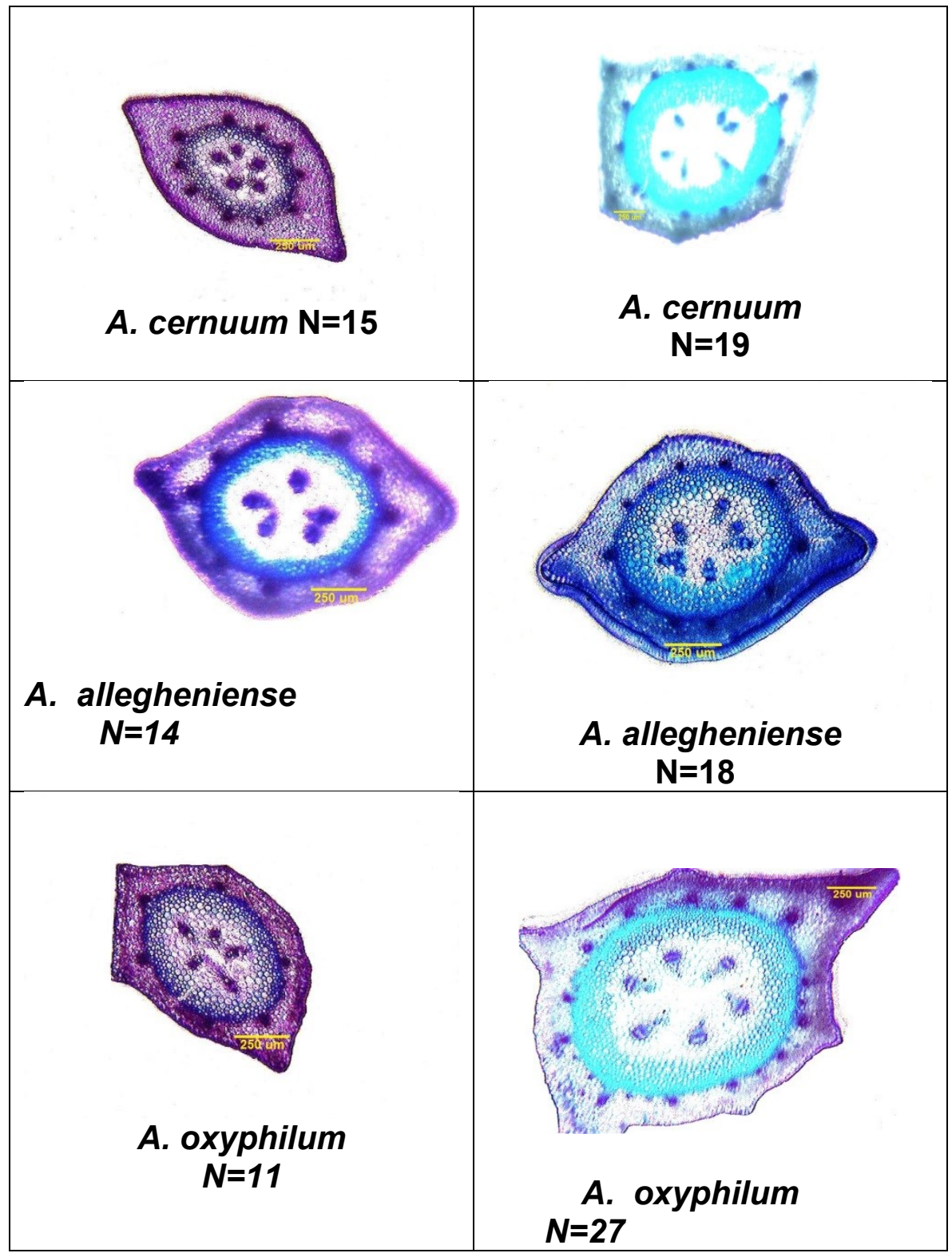

Figure 1-12 Vascular bundle ranges. 


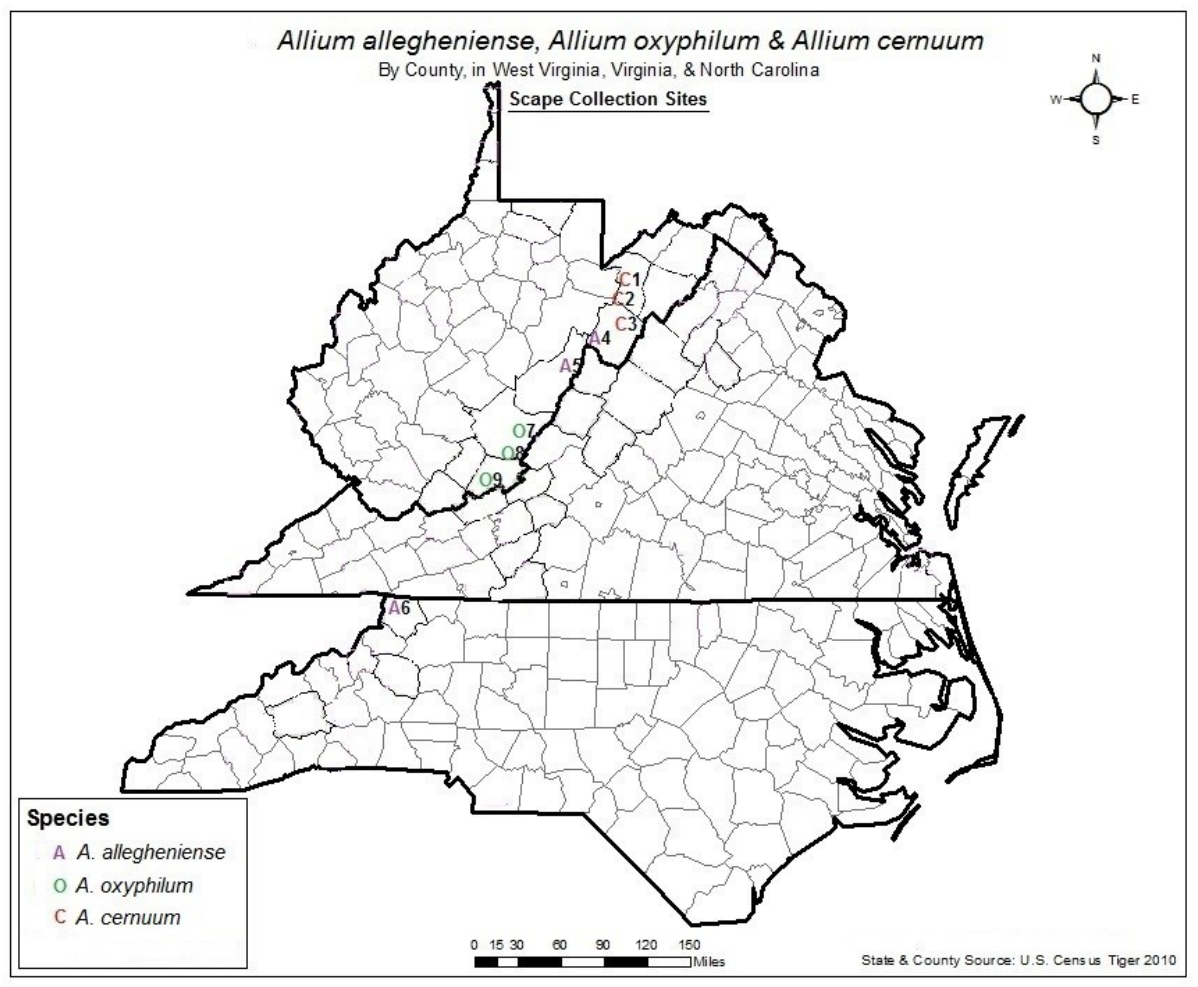

Figure 1-13 Allium population collection sites: 1) Wildcat Road, 2) Cave Mt., 3) Smoke Hole, 4) Circleville, 5) Sheets Road, 6) Paddy Mt., 7) Anthony Creek, 8) Kate's Mt., and 9) Lilydale Road. 
The Allium cernuum Complex in Appalachia: Common Garden and Reproductive Biology

\begin{abstract}
Forty-five mature plants of the Allium cernuum complex were collected from nine populations in West Virginia and North Carolina in the summer of 2008. These were planted in a common garden to study whether the local variations among populations (putative species) are genetically or environmentally determined and to investigate phenology and life history. Phenotypic differences among the species were maintained in cultivation, however flowering periods overlapped. The flowers appeared to be outcrossing, as the open-pollinated common garden produced the most seed set in contrast to an insect excluded experiment.
\end{abstract}

To investigate the breeding system of the Allium cernuum complex in Appalachia, a crossing experiment was performed in an insect excluded setting. Prior to blooming, six representatives of each of the three putative taxa were arranged into two sets of nine, one to act as pollen donors and the other to act as pollen recipients. Flowers in the functionally female group were emasculated (stamens removed) to prevent selfing. Plants were also tested for autogamy. Apomixis was not demonstrated but a low level of self-compatibility was observed. Passive (unassisted) selfing in $A$. oxyphilum was double that of $A$. cernuum or $A$. allegheniense (based on seed production/flower). A single putative allogamous cross was successful between A. cernuum and $A$. oxyphilum.

\title{
Introduction
}

The purpose of this research is to elucidate the role of habitat and breeding system in the differing morphology found in the Allium cernuum complex. As with the other members of the subgenus Amerallium, there is no dormancy. These plants stay green throughout the year, and the winter cold only slows growth (Rabinowitch and Currah 2002). Nevertheless, these 
Alliums are only distinguishable when in flower. Indeed, the most prominent morphological characteristic for field identification is flower color.

The commonest member of the complex, Allium cernuum, also has the distinction of being the most widespread North American Allium (Fig. 1-1). It is found in a varied range of habitats from open prairies to forests. This adaptable bulb is utilized by the horticultural trade as an ornamental for perennial borders (Rabinowitch \& Currah 2002). Generally the flower color is pale pink, but white variants are not uncommon. The perianth is campanulate (flared) with acute tepals (Fig. 2-1).

Allium allegheniense is found in the rocky highlands of the southeast United States, mostly in North Carolina, Virginia and West Virginia (Fig. 1-10) on amphibolite and mafic outcrops (Weakley et al. 2012). These rocks contain magnesium (Ma) and iron (Fe) but can be low in essential plant nutrients such as nitrogen, phosphorus, potassium and calcium (Pepper 2001). The flower color is a reddish-purple hue, and the perianth is urceolate (apically constricted) with acute tepals (Fig. 2-2).

In Allium oxyphilum, tepals are white with a green midrib and obtuse apex (Fig. 2-3). The rarest of the three taxa, its scarcity warrants an imperiled conservation status of "G2" (Nature Serve 2009). This regional endemic occurs in West Virginia and Virginia on shale substrate (Fig.1-11). Shale barrens, found only in the central Appalachians, are usually steeply inclined environments consisting of exposed weathered shale, heavily leached soil, often with an acidic $\mathrm{pH}$, and an open canopy structure favoring obligate heliophytes (Vanderhorst 2005).

To investigate possible links between habitat and flower morphology an experimental common garden was created to clarify whether the variation is genotypic (stable) or environmental (plasticity). This experimental garden was in the tradition of Göte Turesson, a pioneer in experimental garden technique. He espoused the view that differentiation among 
plant populations can be genetically based on natural selection and not just phenotypic plasticity, which was then the prevailing view. Such populations, adapted by natural selection to particular environmental conditions, are known as "ecotypes” (Turesson 1922).

The purpose of the crossing experiment was to determine whether the three putative taxa in the Allium cernuum complex can interbreed. Characterizing the breeding systems of plants can be important taxonomically as a means of species circumscription (biological species concept). In cultivated Allium cepa, as with most onions, flowers are perfect and exhibit both self-compatibility and outcrossing. Pollen exchange is usually carried out by insects, along with inputs from wind and gravity (Williams and Free 1974).

\section{Methods: Common Garden}

A common garden was created to determine whether the observed phenotypic variation in the Appalachian Allium cernuum complex is primarily genotypic or environmental. Live collections were made in West Virginia and North Carolina (Fig. 1-13) from regions varied in elevation and rainfall (Table 2-1). Collection sites were determined based on herbarium specimen label data (Fig. 1-2). Precipitation data originates from Morgantown (Hart Field, WV 2009-12) and 40 year annual average precipitation contour maps of West Virginia and North Carolina (National Oceanic \& Atmospheric Administration 2012).

Mature plants were dug up and initially transported with their own substrate in August 2008. The soils from the various collection sites were later mixed to create a uniform substrate. Individuals were planted in plastic pots and randomly placed on an open roof plot to provide a vernalization trigger for blooming. The plot consisted of the 3 putative taxa $\times 3$ populations $\times 5$ individuals per population for a total of 45 plants.

Initially there was one individual per pot, however the founding genet often sprouted additional ramets (offsets) resulting in a clonal colony. Counts were based on all plants within a 
given pot (assumed genetically identical). For each pot, morphological and phenological details were observed on a weekly basis throughout the growing seasons of 2009 and 2010.

Morphological data included number of leaves, leaf length, width, number of scapes, scape length, number of flowers, pedicel length, perianth shape, tepal color, shape and length and number of capsules. Color was measured in daylight using the Royal Horticultural Color Society chart standards (Royal Horticultural Society 2001).

Life cycle data incorporated survival, earliest and latest flower bloom and duration of a typical flower from opening to senescence. Plants were not counted dead until three years without emergence. Pots showing no emergence by the third year (September 2011) were sifted to confirm no viable bulb and discarded.

A two-way ANOVA, with the effects Taxon and Population nested within Taxon, was calculated in SAS-JMP software (2007). The population was set as a random effect, so it could be used as the error term for Taxon.

\section{Methods: Crossing Experiment}

To examine the breeding systems of Allium cernuum, $A$. allegheniense and $A$. oxyphilum, plants were tested for apomixis, self- and cross-compatibility. The crossing experiment was carried out in the Life Science Building greenhouse (WVU, Morgantown) to reduce the likelihood of anemophily or entomophily.

Three plants, one from each species, were selected for apomixis and self-compatibility testing. Apomixis (asexual seed formation) was tested by removing the anthers in five flowers for each species. Testing for passive autogamy (non-assisted self-fertilization) required no manipulation. Active autogamy (assisted self-pollination) involved crossing within one flower (at 
least 5 flowers for each species). Geitonogamy (crossing of different flowers on the same plant) was done with at least 10 flowers for each species and also involved assisted pollination.

Prior to blooming in July 2011, 18 plants (6 individuals X 3 taxa) were divided into two groups of nine pots. All ramets (offsets) in a single pot, assumed to be clones, were treated as a unit. Each group was confined under cheesecloth to exclude pollinators. One set was functionally female while the other provided pollen. The "female" group was emasculated as the anthers emerged. Male and female plants were crossed based on similar stage of flower development (Fig. 2-4).

As the flowers opened they were pollinated. The pollen was either transported on a pair of tweezers or the anther was detached and applied directly to the stigma. Jewelry tags tied to the pedicels designated the parentage and the crossing date. The number of flowers per scape was recorded for each plant. For each of the putative taxa anthesis interval was documented. Seed set was tallied in September 2011.

\section{Results: Common Garden}

Cumulative mortality was $42 \%(19 / 45)$ in the common garden and differed among species $(P=0.01$ chi-square). Allium cernuum had the fewest losses with $27 \%(4 / 15)$ followed by $A$. allegheniense at $47 \%(7 / 15)$ and $A$. oxyphilum at 53\% (8/15). All $A$. cernuum and most $A$. oxyphilum mortality occurred in 2009 at the outset of the experiment. In contrast $A$. allegheniense steadily declined each year (Table 2-2).

A relationship was observed between mortality, annual precipitation, and distance from the common garden site. The populations from areas of higher precipitation and farthest from the common garden plot in Morgantown fared the worst. In particular, mortality was highest in A. allegheniense which also is from areas with greater precipitation $(P<0.001)$ and elevation. 
Mortality was likewise highest among plants collected from greater distances from the common garden site in Morgantown, West Virginia (Table 2-1).

Morphological differences among plants were genotypic, as vegetative and floral characteristics of the individuals remained stable in 2009 and 2010. No significant differences in quantitative morphology were found, with the exception of pedicel length in $2010(P<0.0001$ chi-square). Allium cernuum was significantly shorter, whereas $A$. oxyphilum and $A$. allegheniense were roughly comparable (Fig. 2-5).

The qualitative data (perianth shape, tepal shape, and tepal color) emerged as significant, consistent with the herbarium data (Table 2-3) (Fig. 1-8). Perianth shape $(P=0.0005$ chi-square, $\mathrm{P}<.0003$ chi-square), whether campanulate or urceolate, was consistent in 2009 and 2010 respectively (Table $2-4$ ). Tepal shape remained stable both years and a significant difference $(P=0.001$ chi-square) was observed between species (Tables 2-3, 2-4).

Tepal color $(P<0.001$ chi-square) did not change in the common garden in 2009-10 (Table 2-4). The color varied slightly within population but was constant in each individual every year. Tepals have a gradual range of color from base to apex, exhibiting the deepest color along the mid-vein. Allium cernuum and A. allegheniense fell within different hues of the 'purple group' (RHS 2001). A few pale, almost white, $A$. allegheniense were observed in Circleville, West Virginia. Though these contrasted with the population overall, the midrib and base still exhibited purple pigment. Allium oxyphilum is in the 'green group' having white tepals with a greenish base and mid-vein.

A phenological gene flow barrier is not supported as flowering times among the three species overlap (Table 2-5). Bees were noted foraging among the flowers at all sites examined. In the field halictid bees (Halictidae) appeared to be the main pollen vectors, whereas bumble bees (Bombus) were most often observed in the common garden. 
Fruit set (open pollination) was not significantly different among the species, but Allium oxyphilum percentage was highest both years. The number of capsules more than doubled in all species in $2010(P=0.046)$ likely owing to the production of flowering ramets (offsets with scapes) (Table 2-6). Seeds of the three species are black and obovoid, with a maximum of three per capsule. In 2013 a seedling became established, five meters from the common garden, in a pot in an adjacent experiment.

\section{Results: Crossing Experiment}

Allium cernuum is protandrous, as the anthers dehisce before the stigma elongates, thus enhancing the probability of outcrossing. Inflorescences bloom centripetally: as an umbel breaks free from the spathe, outer flowers open first. Individual flowers remained open for 7 to 15 days before senescence. No emasculated flowers bore fruit so apomixis is not supported.

In the greenhouse only a single cross was successful ( $\$$ Allium cernuum $\times \sigma^{\circ} A$. oxyphilum). Each species yielded fruit, apparently the result of passive autogamy, because capsules formed on non-manipulated flowers. Low fruit productivity was found in all taxa excluded from pollinators in the crossing experiment (Table 2-7) in contrast to the common garden output (Table 2-6).

\section{Discussion}

The observed mortality patterns may potentially arise from dissimilar habitat conditions. Perhaps these species are adapted to specific edaphic, temperature or precipitation factors and were stressed by the intermingled homogenous soils of the common garden. Plants from wetter regions might have fared worse in Morgantown's lighter precipitation. Allium allegheniense populations were generally observed in the higher elevations and wetter regions, according to precipitation maps (Table 2-1). Alternatively, the initial die offs may be attributed to stress in transit over longer distances during the collection process. All $A$. cernuum and most $A$. 
oxyphilum mortality occurred in 2009 (outset of the experiment) suggesting transplantation shock may have played a role (Table 2-2).

Allium oxyphilum seems to occur exclusively on shale barrens. These hostile habitats possess the least true soil and humus of any upland forest association in the eastern United States. Though variable, the $\mathrm{pH}$ is frequently acidic, especially in steep exposed terrain (Allard 1946). This combination of variables is detrimental to all but a few hardy species. Harsh environments can catalyze evolution and may explain the characteristic endemism of the shale barrens and the unique morphology of $A$. oxyphilum in particular.

Geographic isolation also has a role in speciation as organisms inhabiting dissimilar soils become reproductively separated. Selective pressures associated with edaphic endemism may provide a refuge from competition by favoring adapted organisms or excluding nonadapted species. Hybridization between tolerant and intolerant neighbors would likely result in reduced fitness in either niche (Pepper 2001).

Shale barren endemism may have a counterpart in the serpentine outcrops of western North America where exposed ultramafic features are hypothesized to drive Allium diversification. Such outcrops are believed to promote speciation in Allium and have been used to explain the rich source of the Allium diversity in the region (Nguyen 2008).

The flowering periods among putative taxa overlap so that seasonal isolation seems unlikely (Table 2-5). If there is a difference, as alluded to in Strausbaugh and Core (1977), it may have been temporarily displayed in the common garden. In Allium unifolium, environmental effects can carry over from a previous location affecting blooming time (Kodaira et al. 1996). Such influences were perhaps a factor in the first year (2009) of the common garden experiment in which $A$. oxyphilum bloomed 8 days later and persisted 17 days longer 
than in 2010. Lingering effects from the original habitat might explain the disparity compared to later years.

The morphological characteristics of the three putative taxa remained stable in the common garden. Quantitative features were consistent within individuals and flower traits were unchanged each year. Matching earlier descriptions (Wherry 1925, Strausbaugh and Core 1977), long pedicels were observed in Allium oxyphilum (Fig. 2-5).

Small's (1899) distinction between campanulate vs. urceolate (Allium allegheniense) perianth shape is supported. In the common garden the shortest tepals were in $A$. allegheniense, however notched tepals, indicated by Small, were not observed. The $A$. oxyphilum green mid-vein is useful in distinguishing $A$. oxyphilum from other white blooms that simply lack pigment (Fig. 2-3).

In the crossing experiment the lack of fruit set could be due to genetic incompatibility between the plants. Each species is somewhat self-compatible, even yielding fruit $(2-4 \%)$ apparently the result of passive autogamy. The common garden had far greater seed production, but it is unknown which plant was pollinated by which, only that wind or insects were the likely agents. Chris Cramer (New Mexico State University) reports (pers. comm.) poor seed set with Allium cepa hand pollinated in the greenhouse compared to enclosing plants in plastic screen cages and introducing pollinating flies, which are highly efficient. Perhaps a better method of crossing would involve using insects in multiple separate cages.

Poor synchronization of stigma and pollen readiness could have impacted the experimental crosses, as it was not verified when pollen was viable or when the stigma became receptive. Stigma receptivity in some Allium is signaled by the production of sticky exudate facilitating pollen capture (Currah 1978). However, this phase was not observed in the $A$. 
cernuum complex. The single fruit produced (putative inter-species cross) may have been the result of pollen contamination.

Self-fertilization may lead to inbreeding depression, an important constraint selecting against selfing. Nevertheless even with strong inbreeding depression, selfing is a superior alternative to remaining unfertilized. It can provide reproductive assurance in inhospitable environments, where population density is low or pollinators scarce. Selfing may also maintain established genotypes, such as Allium oxyphilum, by preserving adaptation to stable yet restrictive habitats. Genes from remote populations may be adapted to dissimilar environmental conditions and thus potentially deleterious. Selfing may prevent the import of such unfavorable gene combinations as a means of conserving successfully adapted genotypes (Jarne and Charlesworth 1993). Indeed shale barrens are harsh settings with a suite of selective pressures such as exposure, low pH and thin soil (Allard 1946).

\section{Conclusion}

Flower color, perianth shape and tepal apex were found to be stable in a uniform habitat such that three species can still be distinguished. Allium allegheniense constantly had an urceolate perianth and was purple in hue, though quite pale in a few plants. In A. oxyphilum pedicel length was the longest and the obtuse tepals were white with a greenish midrib and base. However, no phenological differences among species were detected and an anthesis disparity indicating seasonal isolation is not supported.

Limited self-compatibility was demonstrated, with no cross-species reproduction except for a single fruit. However, fruit set was high in the open-pollinated common garden. More crosses should be attempted with additional plants, after confirming pollen viability and stigma receptivity parameters. Flower scarcity was a limiting factor as pollen exchange is only possible when flowers are open contemporaneously. 


\section{References Cited}

Allard, H.A. 1946. Shale barren associations on Massanutten Mountain, Virginia. Castanea 11(3): 71-124.

Currah, L. and D.J. Ockendon. 1978. Protandry and the sequence of flower opening in the onion (Allium cepa L.). New Phytologist 81: 419-428.

Jarne, P. and D. Charlesworth.1993. The evolution of the selfing rate in functionally hermaphrodite plants and animals. Annual Review of Ecology and Systematics 24: 44166.

Kodaira, E., G. Mori, M. Takeuchi and H. Imanishi. 1996. Effects of temperature on the growth and flowering of Allium unifolium Kellogg. Journal of the Japanese Society for Horticultural Science 65(2): 373-380.

National Oceanic \& Atmospheric Administration. 2012. NOAA (www.ncdc.noaa.gov). National Environmental Satellite, Data, and Information Service, Asheville, NC.

Nguyen, N.H., H.E. Driscoll, and C.D. Specht. 2008. A molecular phylogeny of the wild onions (Allium; Alliaceae) with a focus on the western North American center of diversity. Molecular Phylogenetics and Evolution 47(3): 1157-1172.

Pepper, A.E., and L. E. Norwood. 2001. Evolution of Caulanthus amplexicaulis var. barbarae (Brassicaceae), a rare serpentine endemic plant: A molecular phylogenetic perspective. American Journal of Botany 88(8): 1479-1489.

Rabinowitch, H.D. and L. Currah. 2002. Allium Crop Science: Recent Advances. CABI Publishing, NY. 
Royal Horticultural Society Colour Chart. 2001. Ed. 1. The Society, London, UK.

SAS-JMP. SAS Inst., Inc. 2007. Version 7.01. SAS Institute, Cary, NC.

Small, J.K. 1899. Undescribed species from the southern United States. Bulletin of the New York Botanic Garden 1: 278-280.

Strausbaugh, P.D. and E. L. Core. 1977. Flora of West Virginia, 2nd Edition. Seneca Books Inc., Grantsville, WV.

Turesson, G. 1922. The genotypical response of the plant species to the habitat. Hereditas 3: 211-350.

Vanderhorst, J. 2005. The hot zone: the shale barrens of eastern West Virginia. West Virginia Wildlife, West Virginia Division of Natural Resources 5(3): 4-6.

Weakley, A. S., J.C. Ludwig and J.F. Townsend. 2012. Flora of Virginia. Botanical Research Institute of Texas Press, Fort Worth, TX.

Wherry, E.T. 1925. A new acid-soil onion from West Virginia. Journal of the Washington Academy of Sciences 15: 370-371.

Williams, I.H. and J.B. Free. 1974. The pollination of onion (Allium cepa L.) to produce hybrid seed. Journal of Applied Ecology 11(2): 409-417. 


\begin{tabular}{|c|c|c|c|c|c|c|}
\hline Species & Population & County & $\begin{array}{c}\text { Cumulative } \\
\text { Mortality } \\
\text { (out of 5) }\end{array}$ & $\begin{array}{c}\text { Distance } \\
\text { km }\end{array}$ & $\begin{array}{c}\text { Elevation } \\
\mathbf{m}\end{array}$ & $\begin{array}{c}\text { Average } \\
\text { Annual } \\
\text { Precipitation } \\
\text { mm }\end{array}$ \\
\hline Common Garden & Morgantown & Monongalia & n/a & 0 & 303 & 1067 \\
\hline A. cernuum & $\begin{array}{l}\text { Wild Cat Rd., } \\
\text { WV }\end{array}$ & Grant & 1 & 169 & 350 & 864 \\
\hline A. cernuum & Cave Mt., WV & Grant & 1 & 188 & 854 & 965 \\
\hline A. allegheniense & Circleville, WV & Pendleton & 0 & 229 & 654 & 965 \\
\hline A. oxyphilum & $\begin{array}{l}\text { Anthony Creek, } \\
\text { WV }\end{array}$ & Greenbrier & 2 & 298 & 597 & 1067 \\
\hline A. oxyphilum & Kate's Mt., WV & Greenbrier & 2 & 305 & 796 & 1067 \\
\hline A. cernuum & Hinton, WV & Summers & 2 & 325 & 442 & 1067 \\
\hline A. oxyphilum & $\begin{array}{l}\text { Lilydale Rd., } \\
\text { WV }\end{array}$ & Monroe & 4 & 330 & 242 & 965 \\
\hline A. allegheniense & Paddy Mt., NC & Ashe & 3 & 510 & 1,316 & 1346 \\
\hline A. allegheniense & $\begin{array}{l}\text { Three Top Rd., } \\
\text { NC }\end{array}$ & Ashe & 4 & 524 & 981 & 1499 \\
\hline
\end{tabular}

Table 2-1 Collection sites and survival by distance from the common garden. Mortality was greater in plants collected further away from the common garden plot. 


\begin{tabular}{|c|c|c|c|c|c|c|}
\hline Species & $\mathbf{N}$ & $\mathbf{2 0 0 9}$ & $\mathbf{2 0 1 0}$ & $\mathbf{2 0 1 1}$ & $\mathbf{2 0 1 2}$ & Total (\%) \\
\hline A. cernuum & 15 & 4 & 0 & 0 & 0 & $4(27 \%)$ \\
\hline A. allegheniense & 15 & 2 & 1 & 3 & 1 & $7(47 \%)$ \\
\hline A. oxyphilum & 15 & 7 & 1 & 0 & 0 & $8(53 \%)$ \\
\hline Total & 45 & 13 & 2 & 3 & 1 & $19(42 \%)$ \\
\hline
\end{tabular}

Table 2-2 Common garden mortality.

\begin{tabular}{|c|c|c|c|c|c|}
\hline Species & Population & $\begin{array}{l}\text { Perianth } \\
\text { Shape }\end{array}$ & Tepal Color & $\begin{array}{c}\text { Tepal } \\
\text { Apex } \\
\text { RHC } \\
\text { Color } \\
\text { (lightest to } \\
\text { darkest) } \\
\end{array}$ & $\begin{array}{l}\text { Tepal } \\
\text { Shape }\end{array}$ \\
\hline A. cernuum & $\begin{array}{c}\text { Hinton, } \\
\text { Summers Co. } \\
\text { WV }\end{array}$ & campanulate & pink & $\begin{array}{l}\text { purple } \\
\text { n80c }\end{array}$ & acute \\
\hline A. cernuum & $\begin{array}{c}\text { Cave Mt., } \\
\text { Grant Co. WV }\end{array}$ & campanulate & pink & $\begin{array}{c}\text { purple } \\
76 \mathrm{~d}\end{array}$ & acute \\
\hline A. cernuum & $\begin{array}{l}\text { Wild Cat Rd., } \\
\text { Grant Co. WV }\end{array}$ & campanulate & pink & $\begin{array}{c}\text { purple } \\
68 d, 69 d, \\
76 d, \\
\text { n80c }\end{array}$ & acute \\
\hline A. allegheniense & $\begin{array}{l}\text { Paddy Mt., } \\
\text { Ashe Co. NC }\end{array}$ & urceolate & purple & $\begin{array}{c}\text { purple } \\
91 a\end{array}$ & acute \\
\hline A. allegheniense & $\begin{array}{c}\text { Circleville, } \\
\text { Pendleton Co. } \\
\text { WV }\end{array}$ & urceolate & purple & $\begin{array}{c}\text { purple } \\
91 \mathrm{c}, 91 \mathrm{~d}\end{array}$ & acute \\
\hline A. oxyphilum & $\begin{array}{c}\text { Anthony } \\
\text { Creek, } \\
\text { Greenbrier } \\
\text { Co. WV }\end{array}$ & campanulate & white-green & white & obtuse \\
\hline A. oxyphilum & $\begin{array}{c}\text { Kate's Mt., } \\
\text { Greenbrier } \\
\text { Co. WV }\end{array}$ & campanulate & white-green & white & obtuse \\
\hline
\end{tabular}

Table 2-3 Qualitative floral morphology in the common garden. Higher Royal Horticultural Color numbers indicate darker color. 


\begin{tabular}{|c|c|c|}
\hline Character & 2009 & 2010 \\
\hline Tepal Shape & $\mathrm{P}=0.001$ & $\mathrm{P}=0.001$ \\
\hline Tepal Color & $\mathrm{P}<0.0001$ & $\mathrm{P}<0.0001$ \\
\hline Perianth Shape & $\mathrm{P}=0.0005$ & $\mathrm{P}<0.0003$ \\
\hline
\end{tabular}

Table 2-4 Qualitative characters in the common garden were stable and differed among species in 2009-10 (Chi-square tests).

\begin{tabular}{|l|l|l|l|l|}
\hline Species & $\begin{array}{l}\text { Earliest } \\
\text { Flower } \\
\mathbf{2 0 0 9}\end{array}$ & $\begin{array}{l}\text { Latest flower } \\
\mathbf{2 0 0 9}\end{array}$ & $\begin{array}{l}\text { Earliest } \\
\text { Flower } \\
\mathbf{2 0 1 0}\end{array}$ & $\begin{array}{l}\text { Latest flower } \\
\mathbf{2 0 1 0}\end{array}$ \\
\hline A. cernuum & 7 July & 17 August & 6 July & 24 August \\
\hline A. allegheniense & 7 July & 15 August & 6 July & 13 August \\
\hline A. oxyphilum & 16 July & 3 September & 8 July & 17 August \\
\hline
\end{tabular}

Table 2-5 Flowering phenology of the three species.

\begin{tabular}{|l|c|c|c|c|l|l|}
\hline Species & $\begin{array}{l}\text { Scapes } \\
\mathbf{2 0 0 9}\end{array}$ & $\begin{array}{l}\text { Scapes } \\
\mathbf{2 0 1 0}\end{array}$ & $\begin{array}{l}\text { Flowers } \\
\mathbf{2 0 0 9}\end{array}$ & $\begin{array}{l}\text { Flowers } \\
\mathbf{2 0 1 0}\end{array}$ & $\begin{array}{l}\text { Capsules } \\
\mathbf{2 0 0 9}(\% \\
\text { of } \\
\text { Flowers) }\end{array}$ & $\begin{array}{l}\text { Capsules } \\
\mathbf{2 0 1 0}(\%) \text { of } \\
\text { Flowers) }\end{array}$ \\
\hline A. cernuum & 5 & 17 & 173 & 334 & $78(45 \%)$ & $173(52 \%)$ \\
\hline A. allegheniense & 4 & 21 & 136 & 434 & $40(29 \%)$ & $226(52 \%)$ \\
\hline A. oxyphilum & 4 & 7 & 61 & 147 & $54(89 \%)$ & $123(84 \%)$ \\
\hline
\end{tabular}

Table 2-6 Common garden (open pollination) productivity (2009-10).

\begin{tabular}{|l|c|c|c|}
\hline \multicolumn{1}{|c|}{ Species } & Scapes & Flowers & $\begin{array}{c}\text { Capsules (\% of } \\
\text { Flowers) }\end{array}$ \\
\hline A. cernuum & 26 & 543 & $12(2 \%)$ \\
\hline A. allegheniense & 31 & 461 & $10(2 \%)$ \\
\hline A. oxyphilum & 11 & 207 & $8(4 \%)$ \\
\hline
\end{tabular}

Table 2-7 Greenhouse (pollinator exclusion) productivity (2011). 


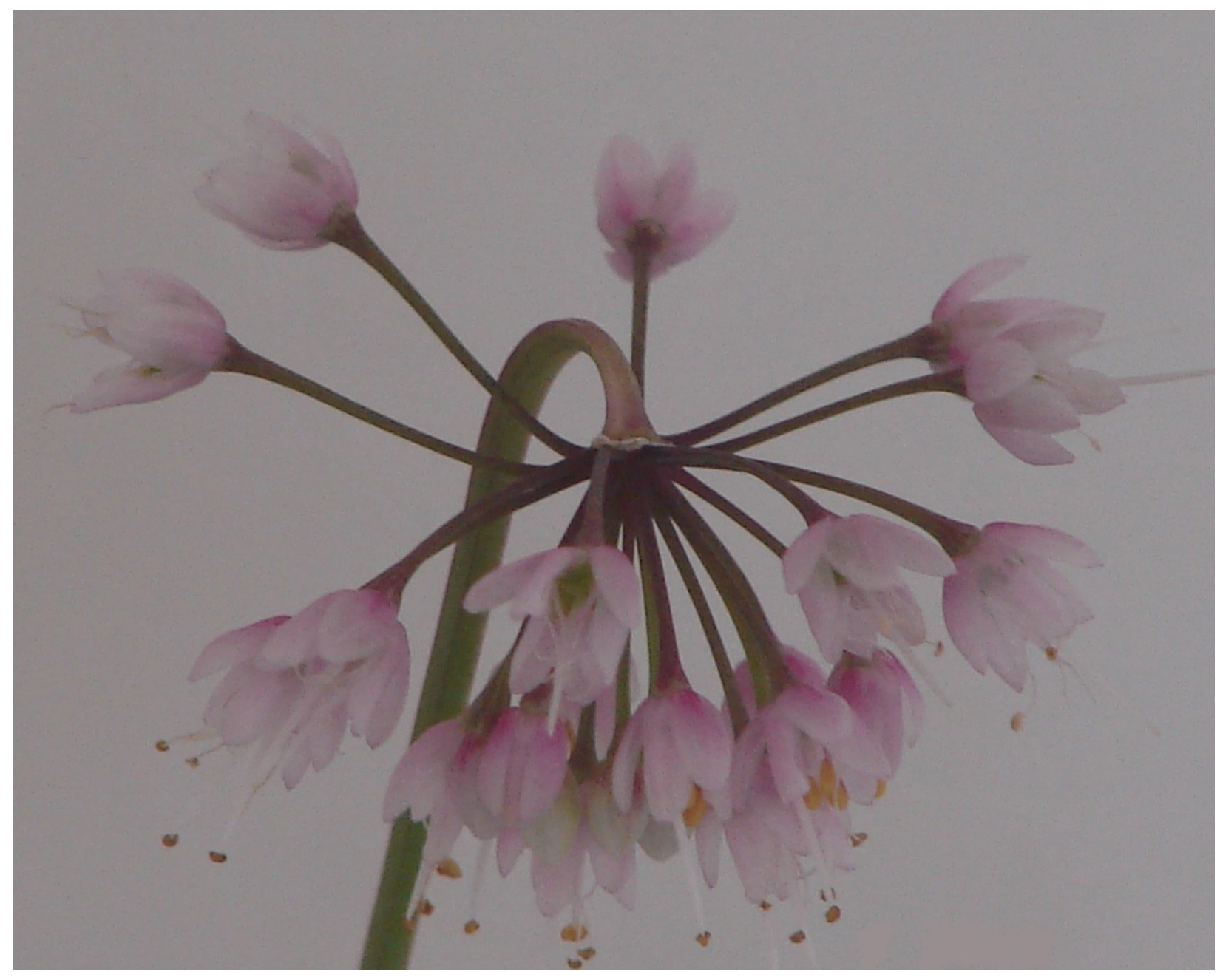

Figure 2-1 Pink flowers of Allium cernuum with campanulate perianth and acute tepals (common garden plant from 2010, Cave Mt. population, Grant County, WV). 


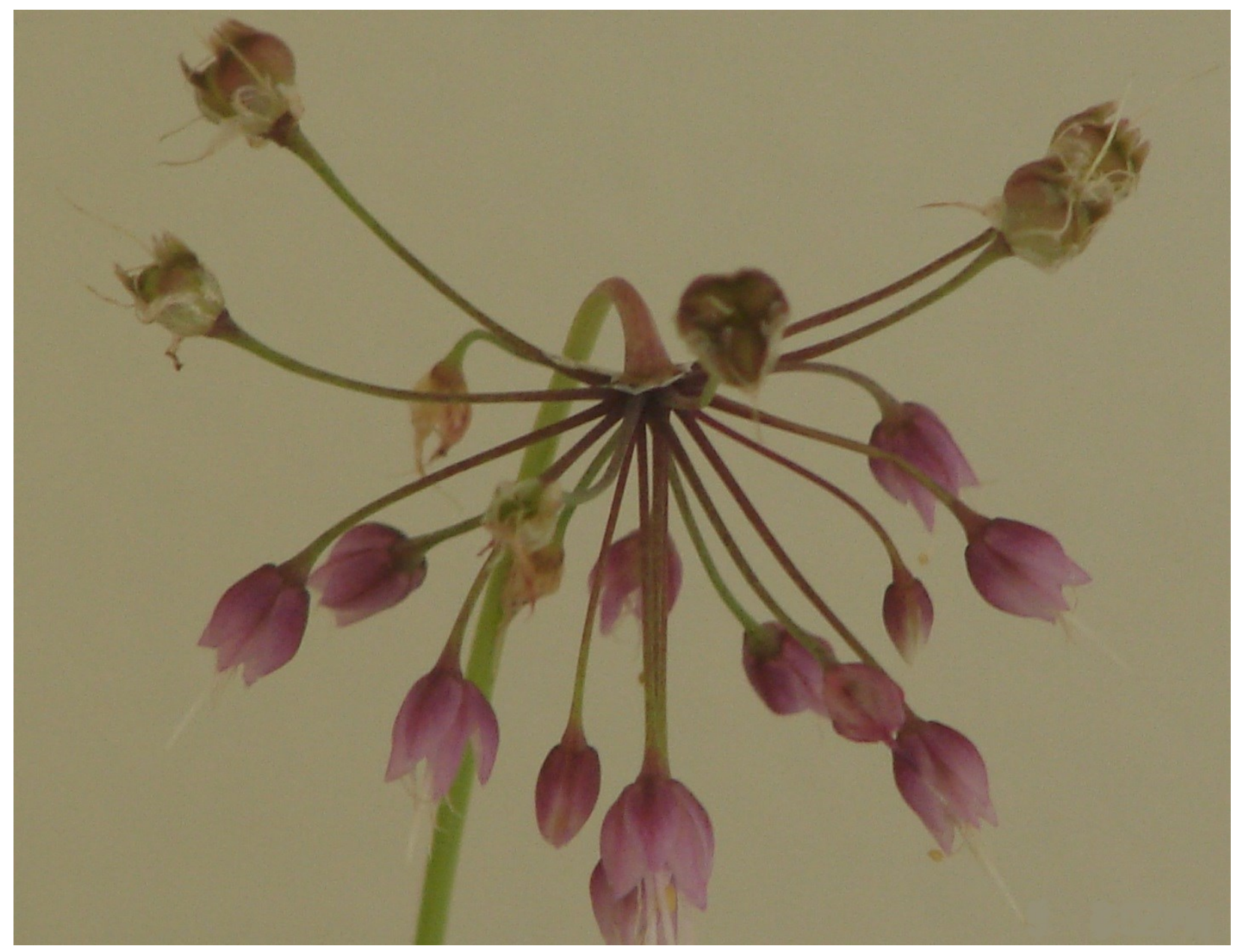

Figure 2-2 Urceolate flowers of Allium allegheniense with purple acute tepals (common garden plant from 2010, Circleville population, Pendleton County, WV). 


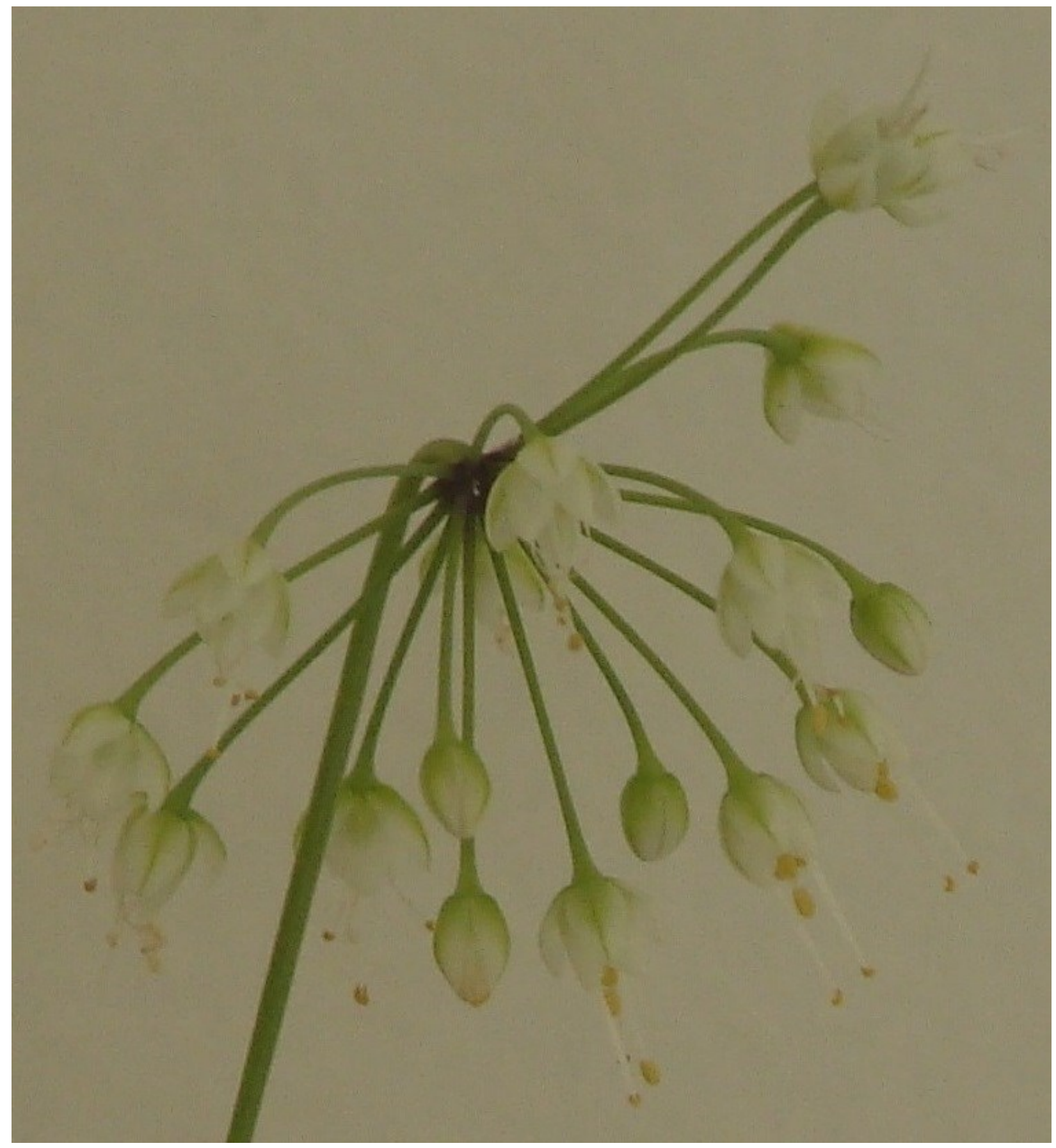

Figure 2-3 Campanulate flower of Allium oxyphilum with white obtuse tepals with green base and midrib (common garden plant from 2010, Anthony Creek population, Greenbrier County, WV). 


\begin{tabular}{|c|c|c|c|c|c|c|c|c|}
\hline $\begin{array}{c}\text { Allium } \\
\text { cernuum } \\
\stackrel{\Upsilon}{q}\end{array}$ & $\begin{array}{c}\text { Allium } \\
\text { cernuum } \\
\mathbf{9}\end{array}$ & $\begin{array}{c}\text { Allium } \\
\text { cernuum } \\
\mathbf{9}\end{array}$ & $\begin{array}{c}\text { Allium } \\
\text { allegheniense } \\
\text { P }\end{array}$ & $\begin{array}{c}\text { Allium } \\
\text { allegheniense } \\
\mathbf{Y}\end{array}$ & $\begin{array}{c}\text { Allium } \\
\text { allegheniense } \\
\mathbf{Y}\end{array}$ & $\begin{array}{c}\text { Allium } \\
\text { oxyphilum } \\
\mathbf{9}\end{array}$ & $\begin{array}{c}\text { Allium } \\
\text { oxyphilum } \\
\mathbf{9}\end{array}$ & $\begin{array}{c}\text { Allium } \\
\text { oxyphilum } \\
\mathbf{9}\end{array}$ \\
\hline $5 x$ & $5 x$ & $5 x$ & $10 x$ & $10 x$ & $10 x$ & $5 x$ & $10 x$ & $6 x$ \\
\hline
\end{tabular}

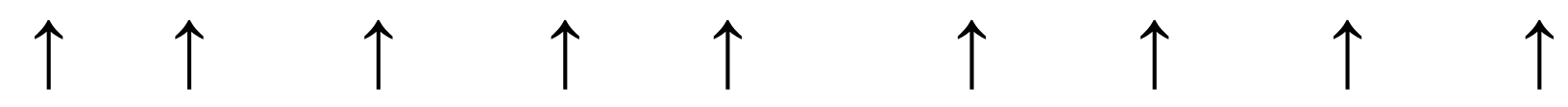

\begin{tabular}{|c|c|c|c|c|c|c|c|c|}
\hline $\begin{array}{l}\text { Allium } \\
\text { cernuum }\end{array}$ & $\begin{array}{c}\text { Allium } \\
\text { allegheniense }\end{array}$ & $\begin{array}{c}\text { Allium } \\
\text { oxyphilum }\end{array}$ & $\begin{array}{l}\text { Allium } \\
\text { cernuum }\end{array}$ & $\begin{array}{c}\text { Allium } \\
\text { allegheniense }\end{array}$ & $\begin{array}{c}\text { Allium } \\
\text { oxyphilum }\end{array}$ & $\begin{array}{c}\text { Allium } \\
\text { cernuum }\end{array}$ & $\begin{array}{c}\text { Allium } \\
\text { allegheniense }\end{array}$ & $\begin{array}{c}\text { Allium } \\
\text { oxyphilum }\end{array}$ \\
\hline & $\sigma^{\top}$ & त्र & $\pi$ & $\sigma^{x}$ & & & $\pi$ & $\pi$ \\
\hline
\end{tabular}

Figure 2-4 The outcrossing experiment with 6 representatives of each of the 3 species, divided into 2 treatment groups of 9 pollen donors $(\sigma)$ and pollen recipients $(\boldsymbol{q}) . \mathrm{X}=$ number of crosses (total 66).

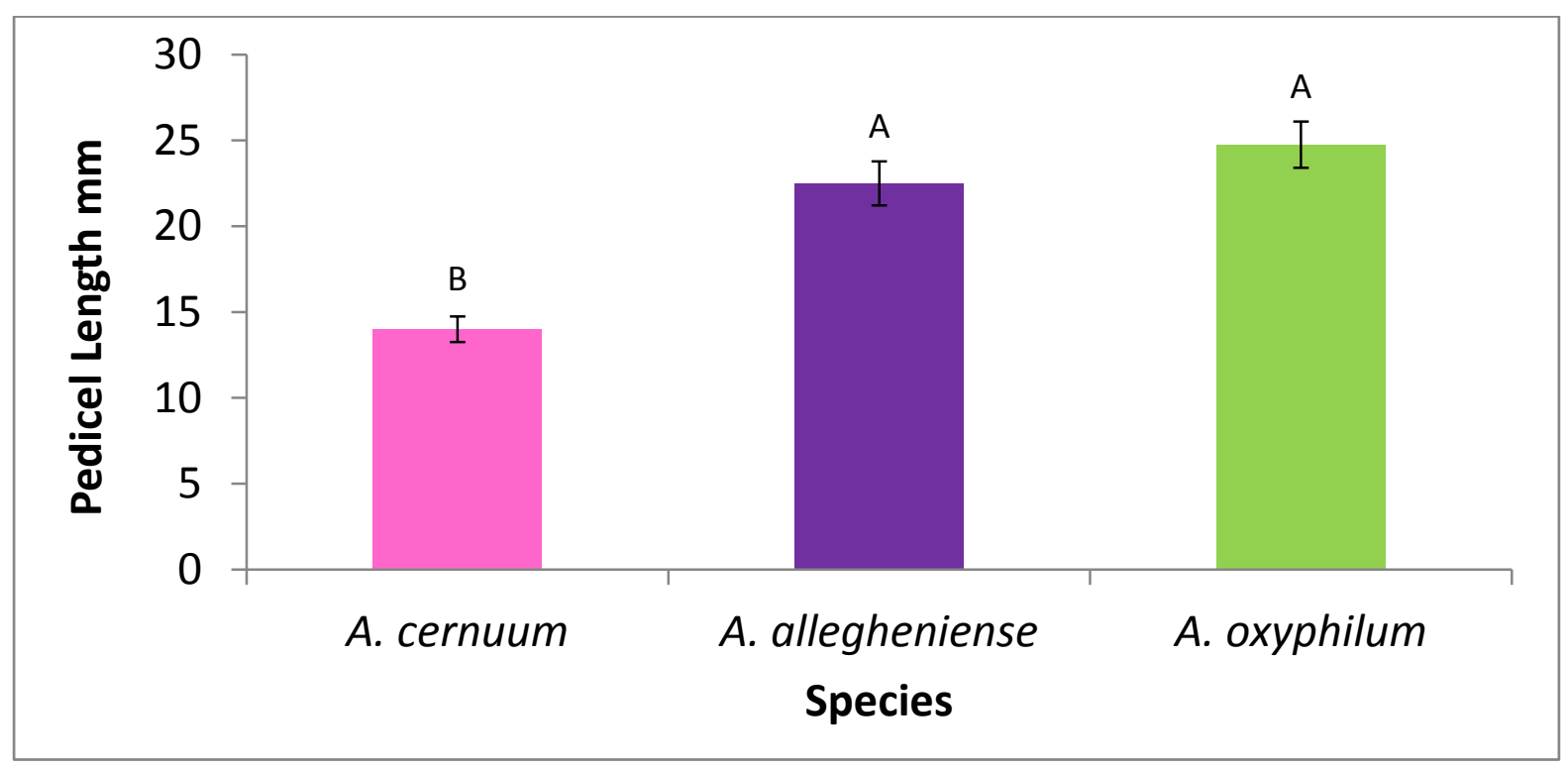

Figure 2-5 Pedicel length in the common garden (2010) was longest in $A$. oxyphilum and $A$. allegheniense. Levels not indicated by the same letter are significantly different. 


\begin{tabular}{|c|c|c|c|c|c|}
\hline Taxon & County & Population & Origin & $\begin{array}{l}\text { Vascular } \\
\text { Bundles }\end{array}$ & ID \\
\hline cernuum & Grant & Wild Cat Rd. & Field & 17 & F 8 \\
\hline cernuum & Grant & Wild Cat Rd. & Field & 19 & F 9 \\
\hline cernuum & Grant & Wild Cat Rd. & Garden & 15 & G 28 \\
\hline cernuum & Grant & Wild Cat Rd. & Garden & 21 & G 30 \\
\hline cernuum & Grant & Cave Mountain & Field & 16 & F 24 \\
\hline cernuum & Grant & Cave Mountain & Field & 17 & F 25 \\
\hline cernuum & Grant & Cave Mountain & Field & 15 & F 26 \\
\hline cernuum & Grant & Cave Mountain & Garden & 14 & G 21 \\
\hline cernuum & Grant & Cave Mountain & Garden & 19 & G 24 \\
\hline cernuum & Grant & Cave Mountain & Garden & 17 & G 25 \\
\hline cernuum & Pendleton & Smoke Hole & Field & 16 & F 10 \\
\hline cernuum & Pendleton & Smoke Hole & Field & 16 & F 11 \\
\hline allegheniense & Pendleton & Circleville & Field & 14 & F 12 \\
\hline allegheniense & Pendleton & Circleville & Field & 16 & F 13 \\
\hline allegheniense & Pendleton & Circleville & Garden & 17 & G 6 \\
\hline allegheniense & Pendleton & Circleville & Garden & 16 & G 7 \\
\hline allegheniense & Pendleton & Circleville & Garden & 17 & G 8 \\
\hline allegheniense & Pendleton & Circleville & Garden & 12 & G 10 \\
\hline allegheniense & Pocahontas & Sheets Rd. & Field & 18 & F 14 \\
\hline allegheniense & Pocahontas & Sheets Rd. & Field & 15 & F 15 \\
\hline allegheniense & Ashe, NC & Paddy Mt. & Garden & 18 & G 3 \\
\hline oxyphilum & Greenbrier & Anthony Creek & Field & 17 & F 16 \\
\hline oxyphilum & Greenbrier & Anthony Creek & Field & 19 & F 17 \\
\hline oxyphilum & Greenbrier & Anthony Creek & Garden & 17 & G 31 \\
\hline oxyphilum & Greenbrier & Anthony Creek & Garden & 15 & G 32 \\
\hline oxyphilum & Greenbrier & Anthony Creek & Garden & 21 & G 35 \\
\hline oxyphilum & Greenbrier & Kate's Mt. & Field & 19 & F 18 \\
\hline oxyphilum & Greenbrier & Kate's Mt. & Field & 26 & F 19 \\
\hline oxyphilum & Greenbrier & Kate's Mt. & Field & 27 & F 20 \\
\hline oxyphilum & Greenbrier & Kate's Mt. & Field & 24 & F 21 \\
\hline oxyphilum & Greenbrier & Kate's Mt. & Garden & 19 & G 38 \\
\hline oxyphilum & Monroe & Lilydale Rd. & Field & 13 & F 22 \\
\hline oxyphilum & Monroe & Lilydale Rd. & Field & 11 & F 23 \\
\hline
\end{tabular}

Appendix Vascular bundle counts including field collected and common garden scapes. 


\section{Acknowledgements}

Sincere thanks to my committee members, Dr. Donna Ford-Werntz, Dr. James McGraw and Dr. Jennifer Hawkins. It is an honor to have known you. I am grateful for the opportunity that you and West Virginia University have provided for the acquisition of research skills.

Many thanks also to George Merovich, of the WVU Division of Forestry \& Natural Resources, for coaching on multivariate analyses.

I thank Eric Hopkins, Andrew Kaufmann and Rebecca Polakovsky of the WVU GIS Center, Department of Geography, for assistance and use of equipment.

Thanks to Dan Wall and Laura Gadd of the North Carolina Department of Agriculture: Plant Conservation Program, for assistance in locating plants in North Carolina.

Thomas F. Wieboldt, of the Massey Herbarium at Virginia Tech in Blacksburg, thanks for your help in tracking populations of Allium oxyphilum in Virginia.

Rodney Bartgis, State Director of the West Virginia Nature Conservancy, thanks for your help with finding populations of Allium allegheniense.

Thanks to Pat Lutsie and Wendy Sites for your tireless assistance with gathering all the lab supplies, and Carol McCarthy, thank you for all your help in the greenhouse.

My research was partly funded by the Earl Core Scholarship. I am indebted to Melvin Brown for his generous endowments to WVU. 